\title{
Expressão de galectina-1 e -3 \\ na Leucemia Mielóide Crônica e \\ sua contribuição para a progressão da doença
}

Tese apresentada ao Instituto de Ciências Biomédicas

da Universidade de São Paulo, para obtenção do

Título de Doutor em Ciências (Imunologia).

São Paulo

2009 


\section{Resumo}

YON, M. A. C. Expressão de galectina-1 e -3 na Leucemia Mielóide Crônica e sua contribuição para a progressão da doença. 2009. 222 f. Tese (Doutorado em Imunologia) Instituto de Ciências Biomédicas, Universidade de São Paulo, São Paulo, 2009.

As galectinas são proteínas solúveis que se ligam a beta-galactosídeos. A expressão alterada de galectina-1 e galectina-3 foi relatada em diferentes tumores, sendo associada, em alguns casos, à aquisição de potencial metastático. Estas proteínas exibem uma variedade de efeitos intra e extracelulares que modulam alguns processos fisiológicos envolvidos na tumorigênese. Dentre eles, adesão, proliferação, migração celular e escape tumoral. No entanto, a expressão destas lectinas e sua contribuição na progressão da leucemia mielóide crônica (LMC) é desconhecida. No presente trabalho, verificamos que a expressão ectópica de BCR-ABL, resultou em aumento de galectina-1, mas não de galectina-3. Além disso, linhagens com atividade tirosina-quinase reduzida pelo mesilato de imatinibe ou expressão de mutante de BCR-ABL quinase deficiente exibiram diminuição nos níveis de galectina-1. Por outro lado, em pacientes com LMC, a maior expressão de galectina-1 foi correlacionada a altos níveis de BCR-ABL, progressão da doença e a um tempo de sobrevida menor. Adicionalmente, as células K562 com galectina-1 inibida por RNA de interferência exibiram crescimento mais lento do que as células K562 com galectina-1 intacta, em camundongos "nude". Em conjunto, nossos dados indicam claramente que somente a galectina-1 é modulada pela atividade tirosina-quinase de BCR-ABL. Ademais, o pior prognóstico de pacientes com altos níveis de galectina-1 sugere um efeito cooperativo de galectina-1 na tumorigênese de BCR-ABL. Isto reforça o conceito de que a galectina-1 é um forte candidato para intervenção terapêutica na LMC.

Palavras-chave: Leucemia mielóide crônica. Galectina-1. Galectina-3. BCR-ABL. Tirosinaquinase. Pacientes. Tumorigênese. 


\section{Abstract}

YON, M. A. C. Expression of galectin-1 and -3 in Chronic Myeloid Leukemia and its contribution to disease progression. 2009. $222 \mathrm{f}$. PhD thesis (Immunology) - Instituto de Ciências Biomédicas, Universidade de São Paulo, São Paulo, 2009.

Galectins are soluble beta-galactoside binding proteins. Altered expression has been reported in different tumors and, in some cases this expression was associated to the acquisition of metastatic potential. Galectins have different intra and extracellular effects that modulate some physiological processes involved in tumorigenesis, including cellular adhesion, proliferation, migration and immune escape. However, its expression and contribution to chronic myeloid leukemia (CML) progression is unknown. We verified herein, that BCR-ABL ectopic expression resulted in higher galectin-1 but not galectin-3 levels. Moreover, cell lines with diminished tyrosine-kinase activity by imatinib mesylate or kinasedeficient BCR-ABL expression showed a reduction in galectin-1 expression. On the other hand, in CML patients, elevated expression of galectin-1 was correlated with high BCR-ABL levels, disease progression and shorter survival time. Additionally, in nude mice, galectin-1deficient K562 cells obtained by RNA interference were less efficient in tumor formation than control K562 cells. Altogether, our data clearly show that only galectin-1 is BCR-ABL tyrosine-kinase dependent. Also, worst prognosis in patients bearing high galectin-1 levels suggest a cooperative role for galectin-1 in BCR-ABL-positive leukemia and support the concept that galectin-1 is a strong candidate for CML therapeutic intervention.

Key words: Chronic Myeloid Leukemia. Galectin-1. Galectin-3. BCR-ABL. Tyrosine-kinase. Patients. Tumorigenesis. 


\section{Introdução}

\subsection{Leucemia mielóide crônica}

A leucemia mielóide crônica (LMC) é uma doença mieloproliferativa, caracterizada por uma expansão clonal de célula tronco hematopoética neoplásica pluripotente (FADERL et al., 1999).

A LMC é responsável por $15-20 \%$ de todos os casos de leucemia, na população adulta ocidental (FADERL et al., 1999). Segundo a Organização Mundial da Saúde (OMS), no Brasil, a incidência anual da LMC é de 1-2 casos a cada 100000 habitantes, números semelhantes aos da Europa e EUA (BRASIL, 2007). Esta incidência é discretamente maior no sexo masculino (2,2 em 100000) do que no sexo feminino (1,4 em 100000) (BRINCKER, 1982; VARDIMAN et al., 2002). Apesar de ocorrer com maior freqüência em adultos, na faixa de 25-60 anos, pode ocorrer também em crianças, representando apenas 3\% dos casos de LMC.

Embora a etiologia da leucemia mielóide seja desconhecida, alguns trabalhos sugerem que um dos possíveis agentes causadores da LMC pode ser a radiação ionizante (CORSO et al., 1995). O primeiro indicativo desta associação foi a maior incidência observada em sobreviventes da bomba atômica de Hiroshima e Nagasaki (FOLLEY et al., 1952), em trabalhadores de usinas nucleares assim como em indivíduos submetidos a procedimentos médicos que emitem baixas doses de radiação (NATIONAL RESEARCH COUNCIL (U.S.). COMMITTEE TO ASSESS HEALTH RISKS FROM EXPOSURE TO LOW LEVEL OF IONIZING RADIATION., 2006). Além disso, experimentos in vitro indicaram que uma alta dose de radiação ionizante foi capaz de induzir a formação do neogene $B C R-A B L$ em linhagens celulares em maior freqüência do que as células que não foram irradiadas, apesar da diferença observada não ter sido significativa (DEININGER et al., 1998).

Em 1960, a LMC foi a primeira neoplasia a ser associada a uma anormalidade citogenética característica, graças à descoberta do cromossomo "Philadelphia" (Ph), um cromossomo presente nas células primordiais e suas descendentes (NOWELL e HUNGERFORD, 1960). 
Treze anos mais tarde foi constatado que o cromossomo $\mathrm{Ph}$ encurtado era resultante de uma translocação recíproca $\mathrm{t}(9 ; 22)(\mathrm{q} 34: \mathrm{q} 11)$ entre os braços longos dos cromossomos 9 e 22 (Figura 1) (ROWLEY, 1973). O trabalho de Rowley e cols. permitiu outra descoberta fundamental: a de que o neogene $B C R-A B L$, virtualmente presente em $100 \%$ dos casos de LMC, é resultante da fusão de parte do gene BCR ("Breakpoint Cluster Region") com o protooncogene $c-A B L$ ("Abelson"), localizados respectivamente nos cromossomos 22 e 9 (Figura 1) (BARTRAM et al., 1983; GROFFEN et al., 1984).

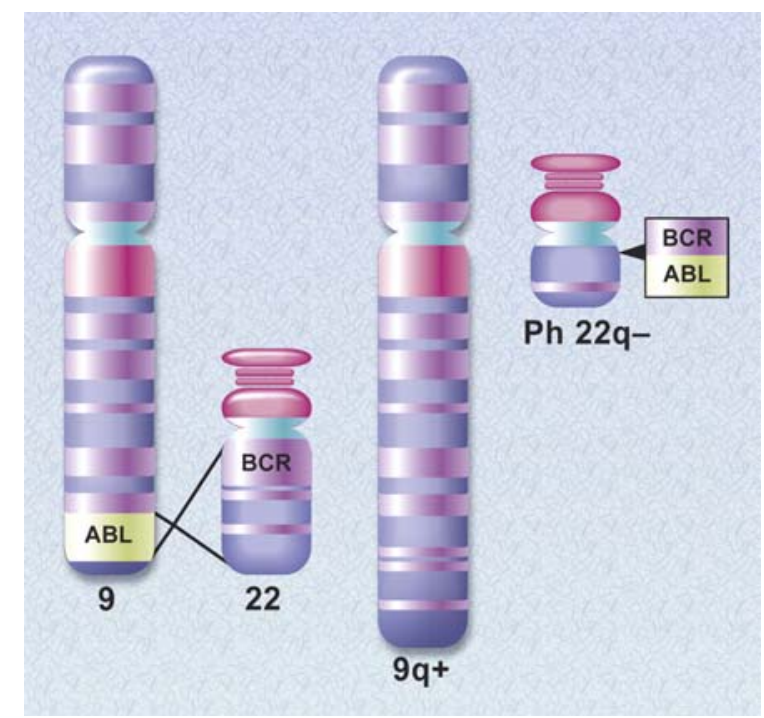

Figura 1 - Esquema da translocação que dá origem ao cromossomo Philadelphia. O gene $A B L$ presente no cromossomo 9 e o $B C R$ no cromossomo 22 sofrem uma translocação formando um neogene, o BCR-ABL.

FONTE: Figura retirada de DRUKER, B. J. et. al, 2008.

\subsubsection{Fases da leucemia mielóide crônica}

Classicamente, a LMC é uma doença de evolução trifásica: fase crônica (FC), fase acelerada (FA) e fase blástica (FB). No entanto, em alguns casos, os pacientes podem desenvolver uma doença de curso bifásico que passa diretamente da FC para a FB, sem passar pela fase intermediária FA (SAWYERS, 1999; MELO et al., 2003). A FC tem progressão lenta com expansão anormal das células granulocíticas que contribui para o aumento de leucócitos circulantes. A doença que se inicia com uma fase crônica, indolente, de duração variável, progride para a FA. Por último atinge a FB que dura geralmente de três a seis meses, resultando inexoralvemente na morte dos pacientes. A grande maioria dos pacientes com 
LMC (80\%) é diagnosticados na FC e apenas 5-10\% na FA ou FB (FADERL et al., 1999; CORTES E KANTARJIAN, 2003a).

\subsubsection{Fase crônica}

A LMC tem início na fase crônica. Os pacientes, nesta fase, não apresentam as características agressivas da doença, não apresentando sintomas. De fato, a incidência de casos assintomáticos aumentou de 15 para 40\%, aproximadamente, nas últimas décadas, provavelmente devido à introdução de análises sanguíneas nos exames de rotina (KANTARJIAN et al., 1993; SAWYERS, 1999).

Nesta fase, quando presentes, os sintomas estão normalmente relacionados à expansão das células leucêmicas. Dentre os sintomas mais comuns, podem ser destacados: fadiga, anorexia, perda de peso, aumento de sudorese, desconforto e saciedade precoce, sendo os dois últimos sintomas causados pelo aumento do tamanho do baço (CORTES et al., 1996; SAVAGE et al., 1997) (Tabela 1). A esplenomegalia e a púrpura são os achados mais comuns do exame clínico de pacientes com LMC. Já nos exames laboratoriais, a leucocitose, trombocitopenia e anemia estão entre as características mais observadas nesses pacientes (SAVAGE et al., 1997) (Tabela 1).

Algumas das mudanças observadas no sangue dos pacientes na FC incluem um predomínio de granulócitos, neutrófilos e liberação de células imaturas da medula óssea (MO), tais como mieloblastos, pró-mielócitos e metamielócitos. O aparecimento, no sangue periférico, de precursores granulocíticos (bastonetes, mielócitos e metamielócitos), que normalmente se localizam na medula óssea é denominado de desvio à esquerda. Assim, uma das características de pacientes na FC é o desvio à esquerda no hemograma (BAIN, 2005). Apesar das alterações, pacientes na FC não são mais susceptíveis a infecções do que indivíduos saudáveis (KANTARJIAN et al., 2006). 
Tabela 1 - Aspectos clínicos e hematológicos da LMC na fase crônica.

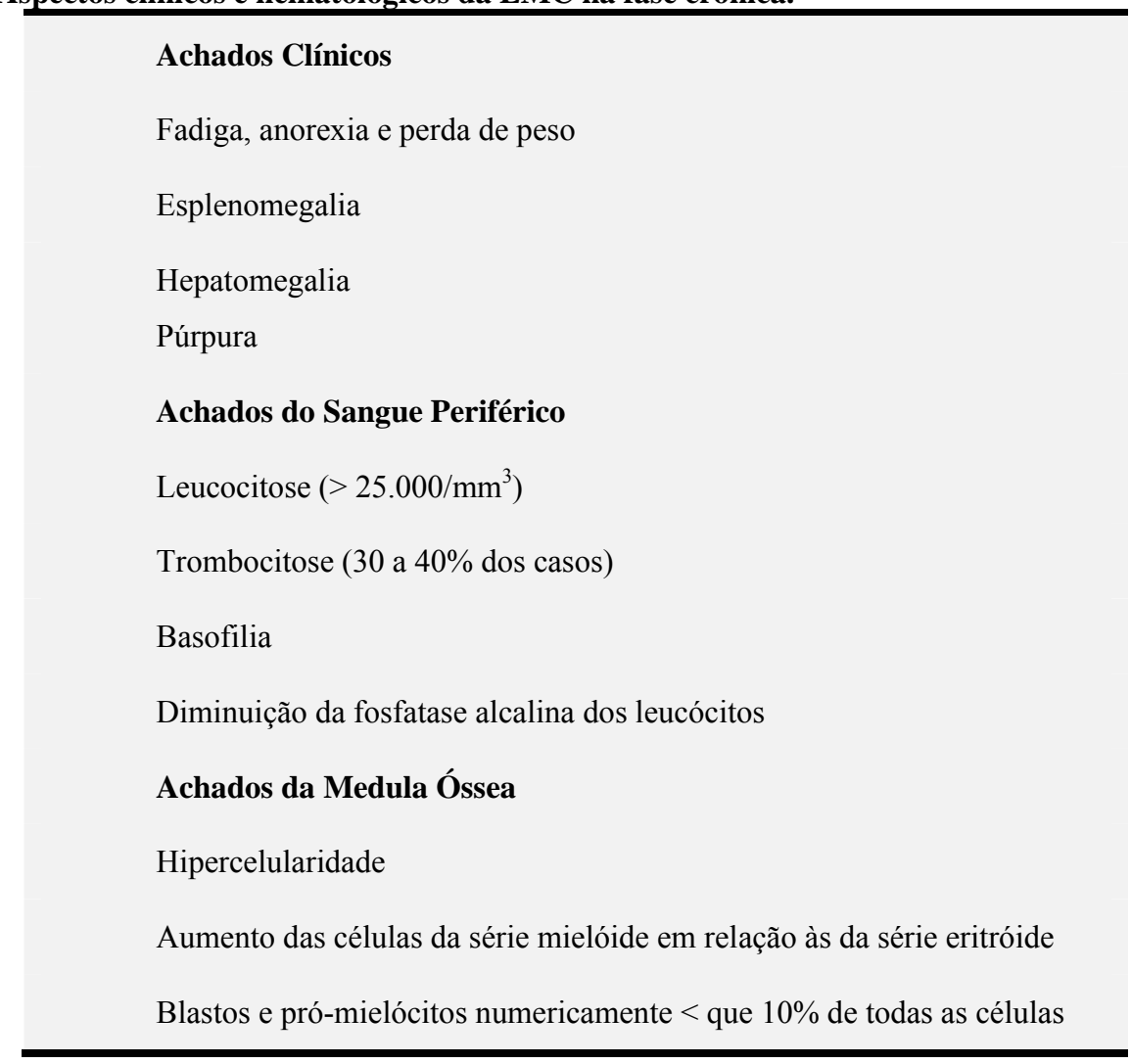

A fase crônica pode durar de três a cinco anos. Após esse período, a LMC evolui para a fase acelerada em $80 \%$ dos casos, enquanto os outros $20 \%$ progridem diretamente para a crise blástica (KANTARJIAN et al., 1993).

\subsubsection{Fase acelerada}

Os critérios de classificação das fases acelerada e blástica variam na literatura. As classificações incluem dados objetivos, tais como porcentagem de blastos e basófilos, assim como dados subjetivos, por exemplo, esplenomegalia persistente e resistência ao tratamento com hidroxiuréia (Tabela 2). É importante estabelecer critérios adequados para a classificação dos pacientes. Isto pode ser exemplificado pelo impacto que a inclusão incorreta de pacientes de fase acelerada na blástica poderia ter na expectativa de vida dos doentes na FB. 
Tabela 2 - Comparação das três classificações da LMC na fase acelerada.

\begin{tabular}{lccc} 
& MDACC (1998) & IBMTR & OMS \\
\hline Blastos (\%) & $\geq 15$ & $\geq 10$ & $10-19$ \\
\hline $\begin{array}{l}\text { Blastos + pró- } \\
\text { mielócitos (\%) }\end{array}$ & $\geq 30$ & $\geq 20$ & NA \\
\hline Basófilos & $\geq 20$ & $\geq 20$ & $\geq 20$ \\
\hline Plaquetas & $<100000$ & $\uparrow$ ou $\downarrow$ Persistente independente & $<100000$ ou $>1000000$ \\
\hline Leucócitos & NA & Difícil controle & NA \\
\hline Anemia & NA & Não responsiva ao tratamento & NA \\
\hline Esplenomegalia & NA & Em aumento & NA \\
\hline Citogenética & EC & EC & EC após diagnóstico \\
\hline Outros & NA & Sarcoma, granulócitos, fibrose & Proliferação de \\
\hline
\end{tabular}

MDACC: M. D. Anderson Cancer Center; IBMTR: International Bone Marrow Transplant Registry; OMS: Organização Mundial da Saúde; NA: Não se aplica; EC: Evolução Clonal.

Fonte: Adaptada do manual de oncologia médica (KANTARJIAN et al., 2006).

Entre as classificações mais usadas estão as do hospital M. D. Anderson Cancer Center (MDACC), do International Blood and Marrow Transplantation Registry (IBMTR) e OMS (Tabela 2).

Em 1988, foi proposta a definição do hospital americano MDACC, freqüentemente utilizada em estudos nos quais os pacientes foram tratados com interferon-alfa e/ou mesilato de imatinibe (MI), um inibidor específico de tirosina-quinase (TK) também denominado de STI571 (descrição na seção 1.1.2.2) (KANTARJIAN et al., 1988). Por outro lado, quando o estudo envolve transplante de medula óssea, as fases avançadas da doença são definidas de acordo com os critérios adotados pelo centro IBMTR.

Em 2002, foi proposta pela OMS uma nova classificação a partir de estudos já publicados (VARDIMAN et al., 2002). Mas, somente alguns anos mais tarde, foi feita uma comparação entre as classificações da MDACC e OMS. Os pacientes tratados com mesilato de imatinibe, que haviam sido classificados de acordo com os critérios da MDACC foram reclassificados com o critério definido pela OMS e a taxa de sobrevivência, entre outros parâmetros, foi avaliada no intuito de definir a utilidade clínica desta nova categorização (CORTES et al., 2006). De fato, os autores mostraram que $10 \%$ dos pacientes estudados 
mudaram de fase com a reclassificação elevando a sobrevivência global dos pacientes na FC. Além disso, os pacientes que apresentavam porcentagem de blastos entre 20 e 29\%, considerados nesta nova classificação, como fase blástica, apresentaram sobrevivência melhor do que os que tinham a porcentagem de blastos acima de $30 \%$. Com esses resultados os autores desse trabalho propuseram uma atualização da antiga classificação do MDACC considerando critérios mais uniformes e menos subjetivos que independam do tratamento utilizado (CORTES et al., 2006).

A mediana de sobrevivência dos pacientes em FA é de um a dois anos, mesmo com o advento de tratamentos com inibidores de tirosina-quinase (VARDIMAN et al., 2002; CORTES e KANTARJIAN, 2003a). Alguns pacientes morrem antes mesmo de alcançar a fase blástica.

\subsubsection{Fase blástica}

O curso natural da doença é o avanço da doença até a última fase, a FB. Entre os sintomas exibidos, podem ser destacados a anemia, aumento no risco de infecções e ou sangramento. Um dos critérios que define a FB é a porcentagem de blastos no sangue ou na medula óssea. Ainda permanece bastante controverso o ponto de corte a ser considerado e, assim, cada classificação estabelece uma porcentagem diferente. Segundo as classificações da MDACC, IBMTR e OMS o paciente é considerado em FB quando apresenta no sangue ou medula óssea uma porcentagem de blastos superior a $15 \%, 10 \%$ ou $20 \%$ respectivamente (Tabela 2). Mais recentemente, foi proposto que essa porcentagem deveria ser superior a $29 \%$ uma vez que pacientes com blastos entre 20-29\% tem sobrevivência maior do que os indivíduos com a porcentagem blastos igual ou superior a 30 (CORTES et al., 2006).

A fase blástica pode ser mielóide (40-70\%) ou linfóide (20-30\%). Apesar desta variável não ser considerada na maioria das classificações, alguns estudos apontam que a FB mielóide tem um prognóstico menos favorável (KANTARJIAN et al., 1987; CERVANTES et al., 1998). A sobrevivência dos pacientes em fase blástica, como citado anteriormente, é de 36 meses. 


\subsubsection{Tratamentos da Leucemia Mielóide Crônica}

Em 1865, foi relatado o primeiro tratamento que trouxe benefícios para os pacientes com LMC. Esta terapia consistia em tratar os pacientes com arsênico, entretanto, este agente não tinha efeito curativo, apenas melhorava os sintomas da doença, reduzindo a quantidade de leucócitos no sangue (ANTMAN, 2001). Por mais de cem anos as terapias empregadas, incluindo radioterapia e tratamento com bussulfan, foram paliativas, melhoraram a qualidade de vida dos pacientes com LMC, sem curá-los.

Somente na década de 80 , surgiu a possibilidade real de cura da LMC, com a introdução do transplante de medula óssea como terapia para esta doença (SPECK et al., 1984). Esta permanece sendo, até hoje, a única forma curativa de tratamento, porém é um procedimento associado a uma alta morbidade e taxa de mortalidade (HEHLMANN et al., 2005).

O desenvolvimento do mesilato de imatinibe (descrito na seção 1.1.2.2), um inibidor específico da atividade tirosina-quinase de BCR-ABL foi um marco no tratamento da LMC (DRUKER et al., 1996). A comprovação clínica dos efeitos deste inibidor motivou a busca por novos compostos, por meio da tecnologia chamada de "drug design". Hoje, novos inibidores estão sendo estudados em ensaios clínicos para verificar eficácia e segurança destas drogas em pacientes com LMC (MELO e CHUAH, 2008).

\subsubsection{Interferon-alfa}

Os intérferons têm sido amplamente utilizados no tratamento de vários tipos de neoplasias, como melanoma, linfoma folicular e sarcoma de Kaposi (JONASCH e HALUSKA, 2001). Por esse motivo, em 1979, Verma e cols. mostraram que uma preparação contendo o intérferon secretado por leucócitos humanos ("human leucocyte interferon" HLIF), quando acrescentada na cultura de granulócitos, causava uma redução no número de colônias e aumento na porcentagem de granulócitos imaturos de forma dose-dependente (VERMA et al., 1979). A partir desse interessante resultado, o interferon-alfa foi introduzido, no início dos anos 80, como tratamento em pacientes (TALPAZ et al., 1983). No entanto, esta terapia foi aceita somente na década seguinte, quando estudos mais amplos apontaram o 
aumento na sobrevida global dos pacientes que receberam o IFN-alfa ao invés de bussulfan (OHNISHI et al., 1995) ou hidroxiuréia (HEHLMANN et al., 1994).

Diversas meta-análises, contemplando os dados obtidos por outros pesquisadores, reforçaram a observação de que o tratamento com interferon-alfa aumentava a porcentagem de pacientes com sobrevida superior a cinco anos em alguns trabalhos e dez anos em outros (CHRONIC MYELOID LEUKEMIA TRIALISTS' COLLABORATIVE GROUP., 1997; BONIFAZI et al., 2001; KANTARJIAN et al., 2003).

\subsubsection{Mesilato de Imatinibe}

A partir da descoberta da alteração molecular BCR-ABL como responsável pela patogênese da LMC, teve início a busca por inibidores desta molécula. Identificado em 1996, o mesilato de imatinibe (MI), originalmente denominado CPG57148B, e também denominado STI571, foi desenvolvido para inibir especificamente a atividade a quinase de c-ABL. O MI, comercialmente denominado Gleevec ${ }^{\circledR} /$ Glivec $^{\circledR}$ (Novartis, Basel, Suíça), tem como alvo a estrutura terciária inativa da quinase c-ABL, mais especificamente, a trinca de aminoácidos Aspartato(D)-Fenilalanina(F)-Glicina(G) (DFG). Ao se ligar a esta trinca, o MI previne a mudança conformacional da proteína e impede, desta forma, a ligação do ATP ao sítio catalítico (Figura 2) (SCHINDLER et al., 2000; NAGAR et al., 2003). Esta pequena molécula é capaz de se ligar também a algumas outras quinases como c-KIT (BUCHDUNGER et al., 2000), mas de forma menos eficaz (ZERMATI et al., 2003).

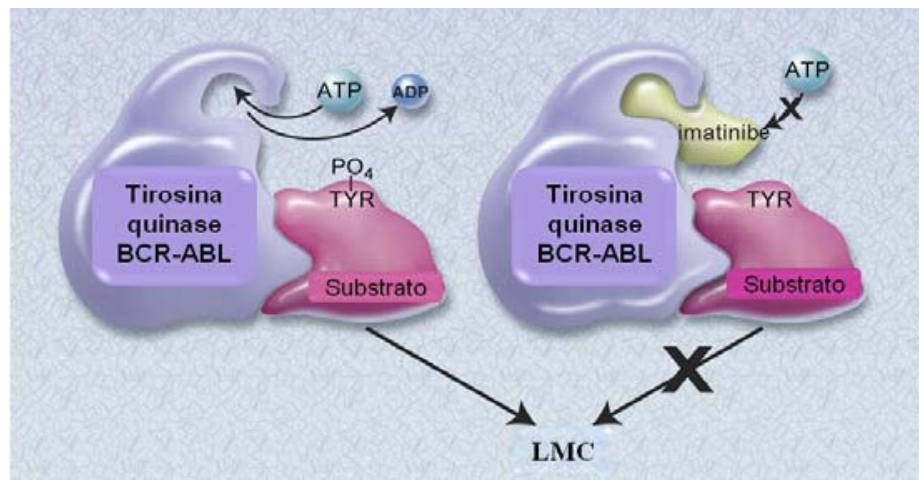

Figura 2 - Esquema do mecanismo de ação do mesilato de imatinibe. O Imatinibe se liga ao sítio da tirosina-quinase de BCR-ABL, bloqueando a ligação do ATP e conseqüentemente inibe a atividade quinase de BCR-ABL.

FONTE: Figura adaptada de Druker, B. J. et. al, 2008. 
Ao se ligar no sítio de ATP de c-ABL, o MI inibe a atividade enzimática desta tirosina-quinase. Os resultados dos experimentos, realizados in vitro, indicaram uma redução na proliferação e formação de colônias de células BCR-ABL-positivas do sangue de pacientes com LMC, mas não tiveram efeito sobre as células normais (DRUKER et al., 1996). Mais tarde ficou provado que o MI induzia somente a morte das células BCR-ABL-positivas (DEININGER et al., 1997).

Dois anos após a descoberta deste inibidor altamente específico, tiveram início os ensaios clínicos de fase I, que avaliaram a segurança e concentração de uso desta droga. Em 1998, doses crescentes de MI (25-1000 mg) foram administradas em 83 pacientes com LMC em fase crônica sem resposta ao tratamento com IFN-alfa. De fato, os efeitos adversos foram mínimos e a dose máxima utilizada foi bem tolerada pelos pacientes (DRUKER et al., 2001).

No ano seguinte, diversos ensaios clínicos de fase II foram iniciados, com pacientes das fases crônica (KANTARJIAN et al., 2002b), acelerada (TALPAZ et al., 2002) e blástica da LMC (SAWYERS et al., 2002) que já haviam apresentado resistência ao tratamento com IFN-alfa que estavam. Em conjunto, estes trabalhos mostraram os efeitos benéficos nos pacientes submetidos à terapia com Glivec ${ }^{\circledR}$.

Logo em seguida, em 2003, a eficácia do mesilato de imatinibe, na concentração de 400mg, ficou comprovada por meio do estudo internacional prospectivo randomizado que comparou a resposta ao tratamento desse inibidor ou de IFN-alfa mais citarabina (Ara C) em 1106 pacientes em fase crônica (O'BRIEN et al., 2003). Os autores desse trabalho observaram que quando tratados com Glivec ${ }^{\circledR}$, uma porcentagem aproximadamente três vezes maior de pacientes permaneciam livres de progressão de doença, quando tratados com Além disso, esse novo tratamento apresentou menor toxicidade, maior aderência e melhor qualidade de vida (HAHN et al., 2003; O'BRIEN et al., 2003).

Devido aos excelentes resultados obtidos nos ensaios clínicos, o Glivec ${ }^{\circledR}$ foi rapidamente aprovado pelo FDA e se tornou tratamento de primeira linha para pacientes em fase avançada da LMC, nos EUA e Europa. No Brasil, o MI foi aprovado pela Agência de Vigilância Sanitária (ANVISA) e introduzido no tratamento do pacientes da Rede Pública em 2001 para pacientes em fase acelerada ou blástica. Apesar dos indicativos da superioridade do tratamento com o STI571 em relação aos outros, o MI só era coberto pelo Sistema Único de Saúde como medicamento de segunda linha, nos pacientes resistentes ao IFN-alfa ou 
intolerantes a essa droga. Finalmente, em junho de 2008, o mesilato de imatinibe passou a ser considerado tratamento de primeira linha e a ter cobertura financeira do SUS, sob a portaria da Secretaria de Atenção à Saúde (SAS) nº 347.

Como na maioria dos tratamentos medicamentosos, alguns pacientes nunca apresentam resposta à terapia inicial com MI, este fenômeno é conhecido por resistência primária. Por outro lado, uma porcentagem pequena dos pacientes perde a resposta que havia sido adquirida e, portanto, passa a ter uma resistência secundária ao imatinibe (MELO e CHUAH, 2007). Este último tipo de resistência é raro na fase crônica, mas à medida que ocorre a progressão da doença, sua freqüência aumenta (HOCHHAUS et al., 2002).

Diversos mecanismos podem ser responsáveis pela resistência ao tratamento com MI, alguns deles podem inclusive atuar de forma concomitante. Por ser um medicamento oral, algumas das causas de resistência primária estão relacionadas com a absorção, metabolização, influxo e efluxo do mesilato de imatinibe. Um estudo recente sobre este último mecanismo levou a identificação de uma proteína denominada hOCT-1 ("human organic cátion transporter-1") que regula a entrada do MI para o interior das células (THOMAS et al., 2004). White e cols. observaram que pacientes com resposta sub-ótima para o Glivec ${ }^{\circledR}$ possuíam uma atividade de OCT-1 menor do que pacientes que responderam ao tratamento, mas que o aumento na dose de imatinibe era suficiente para superar esse problema (WHITE et al., 2007).

A maioria dos estudos, no entanto concentrou-se nos mecanismos envolvidos na resistência secundária. Nesse sentido, vale a pena destacar o trabalho de Hochhaus e cols., no qual os autores, ao estudar 66 pacientes resistentes ao MI, perceberam que 43 deles recidivaram após uma resposta transitória primária, sendo que 33/43 pacientes exibiram uma alteração molecular ou citogenética associada a essa resistência. Nesse sentido, o evento mais freqüente associado à resistência secundária foi a presença de mutações pontuais no domínio de tirosina-quinase de c-ABL, ocorrendo em 23/66 pacientes. Além disso, foram observadas amplificações genômicas de $B C R-A B L$ e alterações cromossômicas em 2/32 e 19/36 pacientes, respectivamente (HOCHHAUS et al., 2002).

As mutações foram observadas em duas regiões do domínio c-ABL: no ponto de contato entre esse domínio e o Glivec ${ }^{\circledR}$ (T315I e F359V) prejudicando a ligação entre eles (CORBIN et al., 2002), e na região da alça P (G250E, Q252H, Y253F/H, E255K/V, M244V) 
que parecem alterar a estrutura conformacional de BCR-ABL da forma iniciativa para a ativa, impedindo também a ligação deste inibidor de tirosina-quinase (SHAH et al., 2002).

\subsubsection{Novas drogas}

Devido a essa resistência, duas estratégias foram abordadas para o desenvolvimento de novas drogas. A primeira consistiu em modificar a molécula de MI para melhorar a afinidade deste inibidor ao domínio de c-ABL. Nesse sentido, pesquisadores da Novartis criaram o Nilotinibe, pelo menos 10 vezes mais potente do que o imatinibe, incluindo a maioria das mutações testadas (exceto a T315I) e mantendo a especificidade pela quinase c-ABL (REDAELLI et al., 2008) (Tabela 3). O Dasatinibe e o Bosutinibe, por outro lado, podem se ligar tanto na forma ativa quanto inativa de c-ABL, sendo cerca de 300 e 200 vezes mais potente do que o imatinibe, respectivamente (REDAELLI et al., 2008). No entanto, nenhum dos inibidores descritos anteriormente atua sobre a mutação T315I (Tabela 3).

Recentemente foi desenvolvido um novo inibidor, o MK-0457, capaz de se ligar ao BCR-ABL com essa mutação (CARTER et al., 2005). Um trabalho inicial com apenas três pacientes mostrou resultados promissores, no tratamento de pacientes que apresentavam essa mutação e que receberam o bosutinibe após desenvolverem resistência contra o imatinibe e dasatinibe ou nilotinibe (GILES et al., 2002) (Tabela 3).

Tabela 3. Comparação entre os novos inibidores de tirosina-quinase de c-ABL

\begin{tabular}{|c|c|c|c|c|c|}
\hline & Ligação & Potência & $\begin{array}{c}\text { Mutações } \\
\text { sensíveis }\end{array}$ & $\begin{array}{c}\text { Alvo(s) } \\
\text { molecular(es) }\end{array}$ & $\begin{array}{c}\text { Fase da } \\
\text { pesquisa }\end{array}$ \\
\hline $\begin{array}{l}\text { Nilotinibe } \\
\text { (AMN 107) }\end{array}$ & Forma Inativa & $\begin{array}{c}30-50 x \\
\text { imatinibe } \\
\end{array}$ & $\begin{array}{c}\text { Maioria } \\
\text { Exceção: T315I }\end{array}$ & $\begin{array}{l}\text { ABL, PDGFR, } \\
\text { KIT, EPHB4 }\end{array}$ & Fase I/II \\
\hline $\begin{array}{l}\text { Dasatinibe } \\
\text { (BMS- } \\
\text { 354825) }\end{array}$ & $\begin{array}{l}\text { Forma inativa } \\
\text { Forma ativa }\end{array}$ & $325 \mathrm{x}$ imatinibe & $\begin{array}{c}\text { Todos } \\
\text { Exceção: T315I }\end{array}$ & $\begin{array}{c}\text { ABL, PDGFR, } \\
\text { KIT, FGR, FYN, } \\
\text { HCK, LCK, } \\
\text { LYN, SRC, } \\
\text { YES, EPHB4 }\end{array}$ & Aprovado \\
\hline $\begin{array}{l}\text { Bosutinibe } \\
\text { (SKI 606) }\end{array}$ & $\begin{array}{l}\text { Forma inativa } \\
\text { Forma ativa }\end{array}$ & $200 \mathrm{x}$ imatinibe & $\begin{array}{c}\text { Todos } \\
\text { Exceção: T315I }\end{array}$ & $\begin{array}{l}\text { ABL, FGR, } \\
\text { LYN, SRC }\end{array}$ & $\begin{array}{c}\text { Fase I/II } \\
\text { Início Fase } \\
\text { III }\end{array}$ \\
\hline $\begin{array}{l}\text { MK-0457 } \\
\text { (VX-680) }\end{array}$ & Forma ativa & $\begin{array}{l}\text { Similar ao } \\
\text { imatinibe }\end{array}$ & $\begin{array}{c}\text { Todos } \\
\text { Inclusive: T315I }\end{array}$ & $\begin{array}{l}\text { Aurora quinases, } \\
\text { FLT3, JAK2, } \\
\text { ABL }\end{array}$ & Fase II \\
\hline
\end{tabular}




\subsubsection{Resposta ao tratamento}

A avaliação da resposta à terapia segue critérios estabelecidos e definidos pelo estudo internacional randomizado do intérferon versus STI571, chamado de estudo IRIS (O'BRIEN et al., 2003). O primeiro parâmetro analisado é a resposta hematológica, seguido pela análise citogenética e por último a molecular (Tabela 4). Considera-se que pacientes que alcançam uma resposta hematológica completa (RHC) têm normalização da contagem normal de leucócitos $\left(<10 \times 10^{9} / \mathrm{L}\right)$, de plaquetas $(<450 \times 109 / \mathrm{L})$ e do tamanho do baço (Tabela 4$)$. Os pacientes em RHC são subdivididos de acordo com a resposta citogenética em: mínima, menor, parcial, completa e maior e também pela resposta molecular que pode ser maior ou completa (Tabela 4).

Tabela 4. Critérios de resposta ao tratamento com inibidores de tirosina-quinase na LMC definidos pelo IRIS.

\begin{tabular}{ll}
\hline $\begin{array}{l}\text { Remissão hematológica } \\
\text { Completa }\end{array}$ & $\begin{array}{l}\text { Normalização da contagem normal e diferencial de leucócitos, desaparecimento dos } \\
\text { sintomas incluindo a esplenomegalia }\end{array}$ \\
Remissão citogenética & Completa+Parcial $\left(0-34 \%\right.$ metáfases $\left.\mathrm{Ph}^{+}\right)$ \\
Maior & $0 \%$ metáfases $\mathrm{Ph}^{+}$ \\
Completa & $1-34 \%$ metáfases $\mathrm{Ph}^{+}$ \\
Parcial & $35-95 \%$ metáfases $\mathrm{Ph}^{+}$ \\
Menor & $>95 \%$ metáfases $\mathrm{Ph}^{+}$ \\
Mínima & \\
Remissão molecular & \\
Completa & $\begin{array}{l}\text { Níveis indetectáveis de transcritos de } B C R-A B L \text { por PCR em tempo real e "nested-PCR" } \\
\text { Maior }\end{array}$ \\
& $\begin{array}{l}\text { Razão entre } B C R-A B L / A B L<0,05 \% \text { ou redução } \geq 3 \text { log de } B C R-A B L \text { a partir da mediana } \\
\text { calculada }\end{array}$
\end{tabular}

FONTE: Adaptado de (KANTARJIAN et al., 2006).

\subsection{BCR-ABL}

A capacidade de uma única molécula, o BCR-ABL, induzir leucemogênese despertou o interesse de muitos pesquisadores. Para uma melhor compreensão da função deste oncogene, vale a pena destacar as funções fisiológicas dos dois genes translocados, $B C R$ e $A B L$ para depois analisar o oncogene e a proteína de fusão resultante, BCR-ABL. 


\subsubsection{BCR}

O gene BCR "Breakpoint Cluster Region” é composto por 25 éxons, incluindo o primeiro (e1') e segundo (e2') éxons alternativos (CHISSOE et al., 1995).

A proteína de $160 \mathrm{kDa}\left(\mathrm{p} 160^{\mathrm{BCR}}\right)$ codificada por este gene tem características estruturais que sugerem uma possível função na transdução de sinais. Este gene é constituído por domínios de serina/treonina quinase (MARU e WITTE, 1991), de adenosina monofosfato cíclico, de oligomerização (MCWHIRTER et al., 1993b), de fator de troca de guanina de Rho GTPase (Rho-GEF) (BOGUSKI e MCCORMICK, 1993), de proteínas ativadoras de RAC GTPase (Rac-GAP) (DIEKMANN et al., 1991) e também de sítios dependentes de cálcio de ligação de lipídeos (BOGUSKI e MCCORMICK, 1993), BAP-1, um membro da família 143-3 de proteínas (REUTHER et al., 1994), e a proteína de reparo de DNA, xeroderma pigmentosa B (XPB) (TAKEDA et al., 1999) (Figura 3).

As regiões mais importantes de BCR são a tirosina 177 e o domínio "coiled-coil" presente no início da região N-terminal (Figura 3). A tirosina 177 por ser o sítio de ligação da proteína adaptadora GRB-2 que permite a ligação do RAS ao BCR (PENDERGAST et al., 1993) e o domínio “coiled-coil”" por promover a dimerização de BCR-ABL, essencial para a ativação da atividade TK (SMITH et al., 2003).

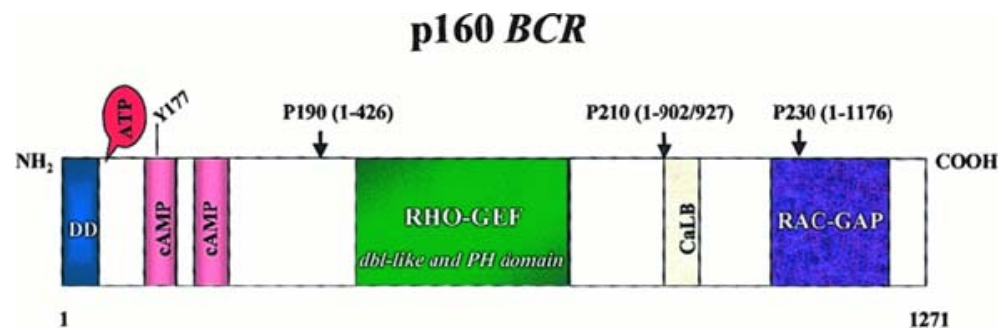

Figura 3 - Esquema da estrutura da proteína BCR. Estão identificados, neste esquema, o domínio de dimerização (DD), dois domínios de adenosina monofosfato cíclico (cAMP), de fator de troca de guanina de Rho GTPase (Rho-GEF), proteínas ativadoras de RAC GTPase (RAC-GAP), sítios dependente de cálcio de ligação de lipídeos (c-ABL). As setas indicam a posição dos locais de quebra das diferentes proteínas de fusão BCR-ABL.

FONTE: Retirada de DEININGER, M. W. et al., 2000.

A função de BCR em células hematopoéticas não está bem definida uma vez que camundongos "BCR-null" possuem um sistema hematopoético aparentemente normal. Estes camundongos não apresentam alterações fenotípicas e se reproduzem normalmente. Somente 
quando os animais recebem doses de endotoxinas foi observada uma alteração no "burst" respiratório de neutrófilos, tornando esses camundongos mais susceptíveis ao choque séptico (VONCKEN et al., 1995).

Em 1996, foi sugerido outro papel de BCR após demonstrarem que o uso de formas mutadas BCR, de peptídeos de BCR fosforilados em Ser-354, mas não em Tyr-360 eram capazes de inibir a atividade quinase tanto de c-ABL como de BCR-ABL. Este trabalho provê indícios de que seqüências presentes no primeiro éxon de $B C R$ são importantes para modular a atividade quinase de c-ABL e BCR-ABL (LIU et al., 1996).

Alguns anos mais tarde, foi observada a ligação de XPB a uma porção do domínio Rho-GEF (TAKEDA et al., 1999) sugerindo uma possível função de BCR na regulação do reparo de DNA por excisão, comprovada posteriormente em linhagens que expressavam a p210 ${ }^{\text {BCR-ABL }}$ (CANITROT et al., 2003).

O ano passado, Perazzona e cols. investigaram o efeito de BCR na expressão de BCRABL. Para tanto, os investigadores expressaram BCR/GFP em células Ton.B210 contendo uma construção induzível de BCR-ABL. Os camundongos "nude", deficientes em linfócitos T e $\mathrm{B}$, inoculados com as células Ton.B210 BCR/GFP que tinham a expressão de BCR-ABL induzida, apresentaram um atraso no aparecimento de tumores e ainda tinham a metade do tamanho dos tumores observados nos camundongos inoculados com as células Ton.B210 BCR/GFP que não expressavam BCR-ABL. No entanto, este mesmo resultado não foi observado com a expressão de um mutante de BCR que torna a atividade TK deficiente. Sendo assim, estes dados sugerem que a inibição de BCR-ABL por BCR requer uma atividade tirosina-quinase (PERAZZONA et al., 2008).

\subsection{2 c-ABL}

O proto-oncogene humano $c-A B L$ é homólogo ao oncogene viral $v-A B L$, originalmente identificado no vírus da leucemia murina de Abelson (A-MuLV). Este retrovírus foi isolado de um camundongo que havia sido inoculado com o vírus da leucemia murina de Moloney (M-MuLV) e sofreu recombinação com o c-ABL murino (ABELSON e RABSTEIN, 1970). Logo em seguida, foi demonstrado o potencial de transformação deste novo retrovírus, A- 
MuLV, que contém o v-ABL, em culturas primárias murinas de fibroblastos NIH3T3 e células linfóides (RASCHKE et al., 1975; ROSENBERG et al., 1975; SCHER e SIEGLER, 1975).

O $c$-ABL humano está constituído de 12 éxons e diversos íntrons (PASTERNAK et al., 1998). Existem duas isoformas resultantes do "splicing" alternativo do primeiro éxon, sendo a isoforma $1 \mathrm{~b}$ miristoilada (AMARANTE-MENDES e GREEN, 1997a).

A proteína c-ABL é ubiqüitariamente expressa em células de mamíferos. Esta tirosinaquinase não atua como receptor. Está preferencialmente localizada no núcleo, mas pode também ser encontrada no citoplasma associada a filamentos de actina (VAN ETTEN, 1999).

A estrutura da proteína c-ABL humana tem uma região amino-terminal muito similar ao da família de sarc (SRC) quinases, seguido por um domínio de homologia de SRC 3 (SH3), domínio de homologia de SRC 2 (SH2) além do domínio catalítico de quinase, o SH1 (Figura 4). A outra região das proteínas da família ABL, por exemplo, do c-ABL de $145 \mathrm{kDa}$ $\left(\mathrm{p} 145^{\mathrm{ABL}}\right)$ é constituída de grande domínio carboxi-terminal de $60 \mathrm{kDa}$, ausente nas SRC quinases que compreende domínios ricos em prolina, consistindo de três seqüências PxxP ( $\underline{\mathrm{P}}$ é prolina e $\underline{x}$ é qualquer aminoácido) com afinidade pelo domínio SH3 de proteínas adaptadoras; domínios de ligação ao DNA; de ligação ao p53, de ligação a proteína Rb, de ligação a actina glomerular e actina filamentosa assim como regiões sinalizadoras de localização e exportação nuclear responsáveis pelo direcionamento de c-ABL para o núcleo ou citoplasma (Figura 4) (NAGAR et al., 2003).

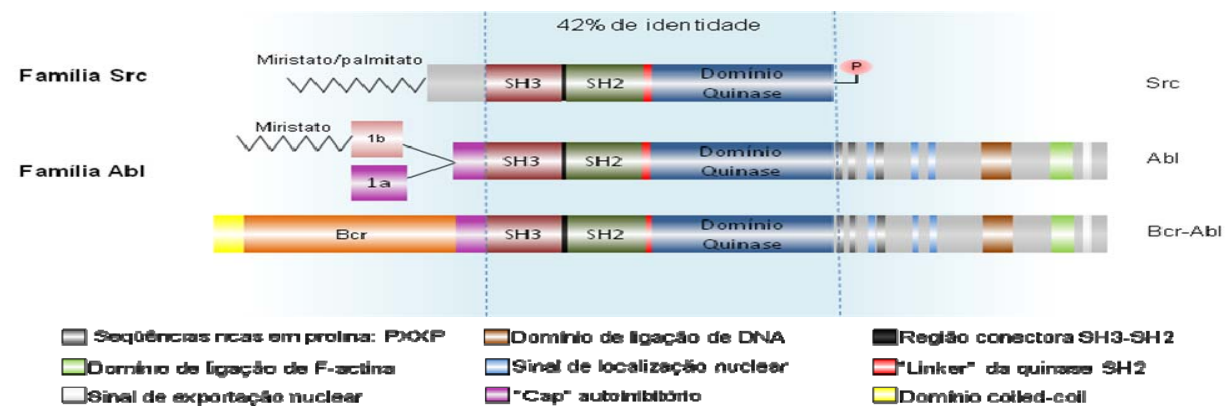

Figura 4 - Esquema da estrutura das proteínas c-Src, c-ABL e BCR-ABL. Domínios estruturais de membros da família SRC e ABL (c-ABL e BCR-ABL). Os sítios de fosforilação não estão representados. A região principal dos três membros é composta pelos domínios de homologia de SRC 3 (SH3), homologia de SRC 2 (SH2) e de homologia de SRC 1 (SH1), também denominado domínio tirosina-quinase. $A$ isoforma $1 b$ de c-ABL é miristoilada, enquanto a isoforma 1a não o é. A escala dos domínios não está representada. ABL: tirosina-quinase Abelson, BCR: “breakpoint cluster region”.

FONTE: Figura adaptada de Hantschel e Superti-Furga, 2004. 
Todos esses domínios de c-ABL permitem uma grande variedade de interações proteína-proteína e proteína-DNA que culminam com sua participação em diversos processos celulares. Entre os efeitos nucleares promovidos por c-ABL, podem ser destacadas a indução de parada no ciclo celular (SAWYERS, 1999) ou apoptose (WANG, 2000; YOSHIDA, 2008) em resposta ao estresse induzido por dano no DNA. Em contrapartida, no citoplasma, o cABL parece estar mais envolvido com a dinâmica da actina e diferenciação (WOODRING et al., 2003). A sinalização mediada por integrinas (LEWIS et al., 1996) ou por fatores de crescimento (FURSTOSS et al., 2002) promove a proliferação de fibroblastos.

\subsubsection{BCR-ABL}

Em células tronco pluripotentes hematopoéticas nas quais ocorreu a translocação dos cromossomos 9 e 22, o gene resultante da fusão de $B C R$ e $A B L$ é o $B C R-A B L$. Os fatores que causam esta translocação não foram elucidados até o momento.

Nesta fusão, o éxon la de $A B L$ é substituído por pedaços variados de $B C R$. De acordo com o ponto de quebra de $B C R$, a fusão dos genes pode dar origem a três proteínas BCR-ABL

distintas: $190^{\mathrm{BCR}-\mathrm{ABL}}, \mathrm{p} 210^{\mathrm{BCR}-\mathrm{ABL}}$ e $\mathrm{p} 230^{\mathrm{BCR}-\mathrm{ABL}}$, associadas respectivamente à leucemia linfóide aguda (LLA), leucemia mielóide crônica (LMC) e leucemia neutrofílica crônica (LNC), diferentes formas de leucemias Philadelphia-positivas (MELO, 1996a). A maioria dos pacientes com leucemia mielóide crônica apresenta o ponto de quebra na região dos éxons originalmente chamados b1-b5 (atualmente éxons 12-16) do BCR, denominada "Major breakpoint cluster region" (M-BCR) (GROFFEN et al., 1991), que justaposto ao c- $A B L$ codifica a isoforma $210{ }^{\mathrm{BCR}-\mathrm{ABL}}$ (CHEN et al., 1988). O ponto de quebra ocorre geralmente ou entre os íntrons b2 e b3 ou b3 e b4, e juntamente com o éxon a2 de ABL formam respectivamente as isoformas b2a2, b3a2 (Figura 5). 


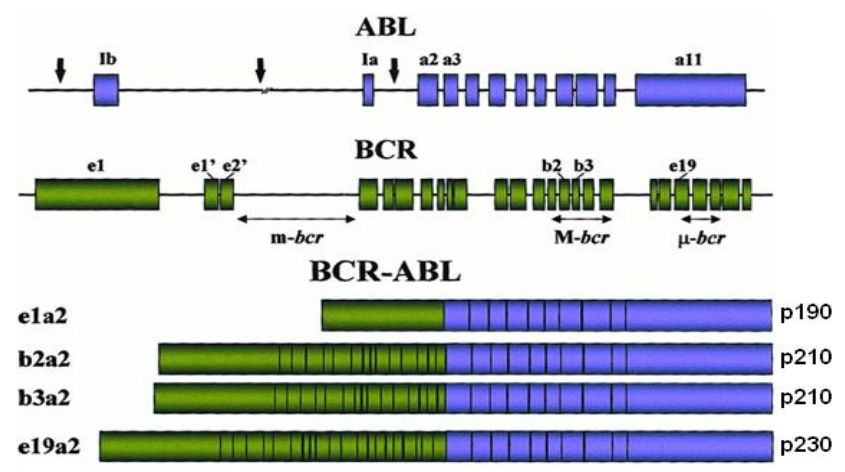

Figura 5 - Esquema dos pontos de quebra nos genes $A B L$ e $B C R$ e RNAm derivado da fusão desses dois genes. Diferentes RNAm (e1a2, b2a2, b3a2 e e19a2) são formados de acordo com a localização do ponto de quebra nos genes $A B L$ e $B C R$, além de especificar o tipo de proteína formada $\left(\right.$ p190 ${ }^{\text {BCR-ABL }}$, p210 $^{\text {BCR-ABL }}$, e p230 $\left.^{\text {BCR-ABL }}\right)$.

FONTE: Retirada de Deininger, M. W. et al., 2000.

Os outros dois pontos de quebra são o "minor breakpoint cluster" (m-BCR) e o "micro breakpoint cluster" ( $\mu$-BCR) que estão associados na maioria das vezes à leucemia linfocítica aguda (LLA), cuja forma observada é a p190 ${ }^{\mathrm{BCR}-\mathrm{ABL}}$ (KURZROCK et al., 1987) e à leucemia neutrofílica crônica $(\mathrm{LCN})$, semelhante a $\mathrm{LMC}$, os sintomas mais brandos e cuja isoforma presente é a p230 ${ }^{\mathrm{BCR}-\mathrm{ABL}}$ (PANE et al., 1996) (Figura 5).

Com a translocação, além do surgimento do neogene BCR-ABL, é transcrito o gene $A B L-B C R$, em aproximadamente $2 / 3$ dos pacientes com LMC, no entanto, sua função permanece desconhecida (MELO et al., 1993).

\subsubsection{Regulação da atividade quinase}

A atividade tirosina-quinase de c-ABL é muito bem controlada. Mesmo quando esta proteína é superexpressa em células hematopoéticas ou fibroblastos, ela não é capaz de transformar estas células (VAN ETTEN et al., 1989). Este controle é efetuado por diferentes mecanismos de auto-inibição de c-ABL, com envolvimento de alguns domínios da própria molécula.

A estrutura conformacional de c-ABL é estabilizada devido a complexas interações intramoleculares que compreendem além do sítio catalítico de quinase, os domínios $\mathrm{SH} 2$ e SH3 (BRASHER et al., 2001), o grupo miroistil, a região conectora SH2-SH3, o domínio "linker" de quinase SH2 e possivelmente a região do "Cap" (HANTSCHEL e SUPERTIFURGA, 2004). Quando a proteína ABL está em sua conformação inativa, os domínios SH2 e 
SH3 permanecem ligados à região distal do sítio ativo (NAGAR et al., 2003). Na realidade, ligações de fosfopeptídeos no domínio SH2 (NAGAR et al., 2003), na alça de ativação (DOREY et al., 2001) e no domínio "linker" de quinase SH2 (BRASHER e VAN ETTEN, 2000) assim como ligações dos inibidores celulares Abi-1 (SHI et al., 1995) e Pag/MSP23 (WEN e VAN ETTEN, 1997) no c-ABL, parecem contribuir para esta modulação.

É interessante notar que a grande maioria das 112 substituições de aminoácidos induzidas por mutagênese aleatória que conferiam aos clones uma resistência ao Glivec, identificadas por Azam e cols., estão localizadas na porção ABL de BCR-ABL. De fato, muitos dos resíduos mutados em BCR-ABL equivaliam às mutações implicadas na desregulação da atividade quinase de c-ABL sugerindo que os mecanismos de regulação destas duas proteínas deviam ser semelhantes (PLUK et al., 2002; AZAM et al., 2003) (BRASHER et al., 2001; HANTSCHEL e SUPERTI-FURGA, 2004).

Um controle adequado da atividade tirosina-quinase de c-ABL é fundamental, pois se sabe que uma falha na regulação desta pode resultar no aparecimento de diferentes tipos de leucemias. Vale à pena destacar o exemplo de BCR-ABL. Neste caso, o processo de fusão do gene $\mathrm{BCR}$ ao $\mathrm{ABL}$ causa alterações, na estrutura conformacional desta, que acarretam na exposição do sítio de ligação de actina (MCWHIRTER e WANG, 1993a), permitem a dimerização de forma constitutiva (MCWHIRTER et al., 1993b), e por fim, parecem interferir também na regulação da atividade de c-ABL pelo domínio SH3 (PENDERGAST et al., 1991). Sendo assim, a perda de regulação de tirosina-quinase de BCR-ABL foi associada ao potencial tumorigênico desta oncoproteína (HANTSCHEL e SUPERTI-FURGA, 2004).

\subsubsection{Propriedades biológicas alteradas por BCR-ABL}

A presença dos variados domínios citados no tópico anterior e a alta atividade TK decorrente da fusão de BCR e ABL conferem a esta oncoproteína a capacidade de ligação e/ou fosforilação de diversas proteínas, com possibilidade de ativação de múltiplas vias de sinalização.

É importante destacar, neste momento, que ao contrário de c-ABL, a localização de BCR-ABL é principalmente citoplasmática e, portanto, muitas vias de sinalização ativadas por BCR-ABL diferem de c-ABL. A ativação destas vias, por BCR-ABL, é responsável pelas 
quatro principais alterações fisiológicas que causam a transformação maligna de células normais (HANAHAN e WEINBERG, 2000). São estas, a adesão celular, mitose, independência de fatores de crescimento e apoptose (DEININGER et al., 2000a).

\subsubsection{Adesão celular}

As células hematopoéticas progenitoras normais se ligam ao estroma da medula óssea via receptores $\beta 1$ integrina para fibronectina (HURLEY et al., 1995). Atualmente, acredita-se que o processo de adesão é essencial não somente para a ancoragem das células progenitoras, mas também para a regulação da hematopoese, incluindo proliferação e apoptose destas.

A proliferação acentuada e a liberação prematura de células progenitoras e precursoras hematopoéticas estão entre as características clínicas da LMC (KANTARJIAN et al., 1985). Um dos mecanismos sugeridos para explicar esses dois fenômenos é a de que a adesão das células progenitoras $\mathrm{Ph}^{+}$à matriz extracelular ou células estromais seja defeituosa. Nessa situação, as células progenitoras deixariam de receber os estímulos que inibem a proliferação (HURLEY et al., 1995) destas células e, além disso, sem uma boa aderência ao estroma medular, estas mesmas células seriam liberadas de forma prematura para a corrente sangüínea (PELLETIER et al., 2004).

Esta hipótese foi corroborada por ensaios realizados, in vitro, que indicaram que a adesão das células progenitoras, obtidas de medula óssea de pacientes com LMC, estava diminuída em relação às células progenitoras de indivíduos normais (GORDON et al., 1987).

Esta perda da aderência foi atribuída, por alguns autores, a possíveis defeitos nos receptores de integrina das células progenitoras ou na sinalização mediada por eles. Os resultados apresentados por Verfaillie e cols., em 1992, reforçam esta idéia. Nesse estudo, as células progenitoras de medula óssea, retiradas de pacientes com LMC, não se aderem bem às células estromais normais ou à fibronectina, mas são capazes de aderir a outras proteínas da matriz extracelular (MEC) tais como colágeno do tipo IV, laminina e componentes da membrana basal (VERFAILLIE, 1992).

Contrastando com essa idéia, outros pesquisadores atribuem a falha na adesão a alterações ocorridas nas células estromais $\mathrm{Ph}^{+}$de pacientes com LMC. Isto porque, células 
progenitoras normais, quando incubadas na presença de células estromais $\mathrm{BCR}-\mathrm{ABL}^{+}$, têm menor proliferação do que na presença de células normais (BHATIA et al., 1995).

Em 2004, foi descrito outro modelo, no qual camundongos deficientes na molécula de adesão P-selectina tiveram uma liberação prematura das células progenitoras mielóides BCR$\mathrm{ABL}^{+}$, acelerando a doença (PELLETIER et al., 2004).

Existe ainda, um conjunto de resultados, que descreve um aumento na adesão tanto de linhagens BCR-ABL positivas como de células progenitoras $\mathrm{CD} 34^{+}$que não pôde ser explicado por uma alteração na função dos receptores de integrina (BAZZONI et al., 1996).

A sinalização envolvida na falha de aderência entre as células progenitoras e o estroma da medula óssea não foram esclarecidas. No entanto, presume-se que a fosforilação de proteínas que participam na organização do citoesqueleto ou membrana celular, possa ter algum papel. A maior fosforilação da quinase de adesão focal (FAK), que promove a adesão celular via sinalização por integrinas, foi observada em células BCR-ABL ${ }^{+}$(GOTOH et al., 1995; SALGIA et al., 1995). Outras moléculas que também são fosforiladas por BCR-ABL, incluindo a CRKL, paxilina, vinculina e tanilina (SATTLER e SALGIA, 1997).

\subsubsection{Proliferação}

Várias vias de sinalização mitóticas são induzidas por BCR-ABL. Entre elas, podem ser destacadas as vias de RAS e proteína quinase ativada por mitógenos (MAPK), de fosfatidinilinositol 3-quinase (PI3-K), de janus quinase (JAK) e fatores de transcrição ativados pela transdução de sinais (STAT), JAK-STAT, e via de MYC.

\subsection{Via de RAS/MAPK}

A proteína RAS fica localizada na superfície interna da membrana plasmática e faz a transdução dos sinais extracelulares. Esta via inicia-se, por exemplo, a partir da ligação de fatores de crescimento no respectivo receptor causando a dimerização deste receptor.

A proteína BCR-ABL é capaz de ativar RAS por meio das moléculas adaptadoras, tais como a proteína 2 ligada a receptor de fator de crescimento, denominada GRB-2, CRKL e 
proteína com domínio SH2, chamada de proteína SHC (MATSUGUCHI et al., 1995). A GRB-2 interage com o domínio de SH2 de BCR-ABL, disponível quando o resíduo 177 de tirosina está autofosforilado (PENDERGAST et al., 1993). Quando isto ocorre, o GRB-2 se liga tanto à proteína "son of sevenless" (SOS) que atua como fator de troca de nucleotídeos de guanina (GEF) formando um complexo BCR-ABL-GRB-2-SOS-RAS que ativa RAS (MATSUGUCHI et al., 1995), quanto à proteína adaptadora GAB2 que ativa a via de PI3-K (SATTLER e SALGIA, 1997).

As outras duas moléculas adaptadoras, CRKL e SHC também podem ativar RAS (ERNST et al., 1994; GOTOH et al., 1995). A importância de CRKL, na ativação de RAS, tem sido discutida uma vez que a ligação direta desta proteína a BCR-ABL não foi necessária para obter a transformação de células mielóides (HEANEY et al., 1997).

O principal alvo do RAS ativado (RAS-GTP) é a MAPK. O primeiro componente da via MAPK ao qual RAS se liga é a serina treonina quinase RAF-1, que por sua vez cataliza a fosforilação de quinases reguladas por quinases ativadas por sinais mitóticos e sinais extracelulares 1 e 2 (MEK 1 e MEK 2) e ERK. Além de ativar ERK, esta via de RAS-MAPK ativada por BCR-ABL, também ativa quinases c-JUN N-terminal (JNK), e quinases ativadas por estresse (SAPK), culminando na fosforilação e ativação de fatores de transcrição de genes (CAHILL et al., 1996).

A via de RAS tem um papel fundamental na transmissão de sinais mitóticos recebidos por receptores de tirosina-quinase (WOOD et al., 1992), além de ser um componente importante na sinalização por fatores de crescimento (REBOLLO e MARTINEZ, 1999) (VARTICOVSKI et al., 1991), afetando os processos de proliferação, sobrevivência e diferenciação (ULKU e DER, 2003).

Diferentes trabalhos mostraram que linhagens $\mathrm{Ph}^{+}$e células primárias de pacientes com LMC, ao serem tratadas com anti-senso para RAS ou construções dominante-negativas de RAS, exibiam uma inibição da proliferação (SAWYERS et al., 1995). Dados obtidos recentemente, utilizando o mutante dominante negativo de RAS, N17 H-RAS, capaz de inibir as três principais isoformas de RAS, indicaram que esta molécula é um alvo crítico para a patogênese de CML causada pelo BCR-ABL. Isto porque o N17-RAS atenuou o desenvolvimento da LMC em camundongos (BAUM e REN, 2008). 


\subsection{Via de PI3-K}

A enzima PI3-K fosforila os fosfatidideos da posição 3' do anel do inositol. A sinalização via PI3-K desempenha um papel importante nos processos de sobrevivência, proliferação, diferenciação, metabolismo entre outros (KHARAS e FRUMAN, 2005).

Esta ativação, por BCR-ABL, pode ocorrer, supostamente, por três vias diferentes (KHARAS e FRUMAN, 2005). A melhor caracterizada e estudada é a via que inclui o complexo GRB2-GAB2 (SATTLER e SALGIA, 1997). BCR-ABL associa-se a esse complexo, fosforilando GAB2, permitindo desta forma a ligação de PI3-K. A ativação desta enzima produz moléculas de fosfatidilinositol-3, 4, 5 trifosfato (PIP3) que se acumulam em células BCR-ABL ${ }^{+}$(VARTICOVSKI et al., 1991). Este produto de PI3-K recruta e ativa proteínas efetoras, por exemplo, AKT (KHARAS e FRUMAN, 2005). O aumento de PIP3 pode ser obtido não apenas pela ativação de sua síntese como também pela diminuição de sua degradação. De fato, a expressão da fosfatase SHIP1 é inibida por BCR-ABL (SATTLER et al., 2001). Além disso, camundongos deficientes em SHIP1 desenvolvem uma doença semelhante à LMC (HELGASON et al., 1998).

Estudos mais recentes, sugerem uma via de ativação alternativa, ainda controversa, por meio de membros da família SRC, do substrato 1 do receptor de insulina (IRS-1) ou RAS. Isto porque, o uso de Dasatinibe, o inibidor de SRC e ABL, foi capaz de anular a resistência de células $\mathrm{BCR}-\mathrm{ABL}^{+}$resistentes ao tratamento com imatinibe (SHAH et al., 2004). Além

disso, pesquisas realizadas em camundongos mostraram que animais deficientes em LYN/HCK/FGR, três membros da família SRC, são resistentes à transformação maligna linfóide induzida por BCR-ABL, mas não à mielóide (HU et al., 2004).

O IRS-1 é um importante mediador de ativação de PI3-K após estímulo dos receptores de insulina, fator de crescimento e citocinas. Este último tipo de receptor é fosforilado, de forma dependente de BCR-ABL, via IRS-1, em células que expressam esse oncogene, participando da ativação de PI3-K (TRAINA et al., 2003).

A importância de PI3K ficou clara com os dados que mostram que sua inibição bloqueia a proliferação em células BCR-ABL dependentes (SKORSKI et al., 1995). Além disso, camundongos deficientes nos genes PIK3R1 e PIK3R, que codificam isoformas de 
PI3K da classe 1A, impediram a transformação, bloqueando a leucemogênese induzida por BCR-ABL (KHARAS et al., 2008).

Ainda nessa via de ativação de PI3-K, outra molécula relevante é a proteína AKT. Sua importância ficou clara em um modelo murino, utilizando um mutante dominante negativo de AKT, no qual foi observado que sem esta molécula, não há transformação de células da medula óssea (SKORSKI et al., 1997).

\subsection{Via de JAK/STAT}

A interação de citocinas com receptores de superfície de membrana iniciam cascatas de sinalização que promovem a proliferação e divisão celular, mas inibem as vias de apoptose (BLALOCK et al., 1999). O fator estimulador de crescimento de colônias de granulócitos e macrófagos (GM-CSF) e a IL-3 são duas citocinas importantes na regulação da proliferação e diferenciação de células mielóides (BAINES et al., 1994). A via de sinalização JAK/STAT, iniciada por essa interação, é constituída por membros da família de Janus (JAK), tirosinaquinases e STAT que fazem a transmissão do sinal do receptor chegar até o núcleo, ativando a transcrição de genes (TAO et al., 2008).

Algumas evidências apontam uma possível ativação da via de JAK/STAT por BCRABL. Por exemplo, em 1990, de Groot e cols. conseguiram mostrar que STAT5 desempenha um papel importante na transformação celular induzida por BCR-ABL, uma vez que o uso de dominante negativo STAT5 prejudicou o desenvolvimento destas células em "soft" ágar, uma característica adquirida na transformação (DE GROOT et al., 1999). Além disso, linhagens hematopoéticas transformadas por BCR-ABL apresentam ativação constitutiva de STAT1, STAT3, mas principalmente STAT5. Estes dados foram reforçados pelo trabalho mais amplo de Chai e cols. que mostraram além da ativação constitutiva de STAT5, a ativação de JAK em um maior número de linhagens BCR-ABL positivas e células obtidas de sangue de pacientes com LMC (CHAI et al., 1997).

Recentemente, foi demonstrado que a transformação mediada por BCR-ABL em fibroblastos murinos primários NIH 3T3 requer ativação da via JAK2/STAT5 via receptor de IL-3 (TAO et al., 2008). No entanto, parece contraditório que STAT5 não seja necessário na indução de leucemia por BCR-ABL, em camundongos (SEXL et al., 2000). 


\subsection{Via de MYC}

Em 1997, Sawyers e cols. mostraram que este fator de transcrição é imprescindível para a transformação causada por BCR-ABL (SAWYERS et al., 1992). Apesar de alguns alvos deste proto-oncogene terem sido relacionados aos processos de apoptose e ciclo celular, muitos permanecem desconhecidos (MENSSEN e HERMEKING, 2002).

Por estar expresso em diversos tipos de tumores, MYC é considerado um protooncogene. Foi observado, em 1998, que os domínios SH2 (AFAR et al., 1994) e c-terminal (OKUDA et al., 1998), presentes no BCR-ABL, são importantes para a ativação de MYC. Além disso, JAK2 parece contribuir para o aumento de MYC pela indução de RNAm deste proto-oncogene e por dar maior estabilidade a proteína de transcrição de MYC, protegendo-a da degradação proteosomal (XIE et al., 2002).

\subsubsection{Apoptose}

A habilidade de expansão de um determinado tumor não depende apenas do índice de proliferação, mas também da taxa de morte das células tumorais, principalmente por apoptose (HANAHAN e WEINBERG, 2000). Na LMC, não é diferente, e acredita-se que a inibição da apoptose mediada pelo BCR-ABL pode contribuir para o desenvolvimento da hiperplasia observada nos pacientes que estão na fase crônica desta doença (LANEUVILLE et al., 1994).

A apoptose é um processo organizado e controlado molecularmente, sendo, por esse motivo, também chamado de morte celular programada. Este fenômeno é caracterizado pela condensação da cromatina, degradação do DNA genômico em fragmentos oligonucleosomais, perda de volume com aumento da granulosidade celular, manutenção da estrutura das organelas e formação de pregas citoplasmáticas que dão origem aos corpos apoptóticos (WYLLIE et al., 1980).

Didaticamente, este tipo de morte celular pode ser dividido em quatro fases (AMARANTE-MENDES e GREEN, 1999). Na primeira, ocorre a transdução de danos físicos ou químicos, em sinais de estresse que, em geral, convergem para o conjunto de mitocôndrias. Estas exercem um papel fundamental, atuando como sensores, monitorando o 
ambiente intra e extracelular. É nas mitocôndrias que esses sinais de estresse são avaliados e, dependendo, principalmente da intensidade do estímulo e da razão entre membros pró e antiapoptóticos da família BCL-2, estes sinais resultarão na liberação de fatores apoptogênicos da mitocôndria para o citosol. Na etapa seguinte, as moléculas liberadas pela mitocôndria, como por exemplo, citocromo c, AIF e SMAC/DIABLO, iniciam uma cascata bioquímica que envolve a ativação de certos membros de uma família de cisteíno-proteases, denominadas caspases, as quais são as responsáveis diretas pelas características morfológicas e bioquímicas da morte celular programada ou apoptose. Por último, essas células em apoptose são reconhecidas e eliminadas por fagócitos ou células adjacentes (GREEN e AMARANTEMENDES, 1998; AMARANTE-MENDES e GREEN, 1999).

Entre os sinais de estresse que ativam a maquinaria apoptótica, podem ser destacados a falta de fatores de crescimento, danos no DNA e ligantes de receptores de morte (ELLIS et al., 1991). Os sinais de estresse podem ativar a apoptose por duas vias. A extrínseca, induzida por ligantes de receptores de morte da família dos fatores de necrose tumoral ("Tumor Necrosis Factor", TNF), e a via intrínseca iniciada, por exemplo, por danos no DNA, cujo sinal é dirigido diretamente à mitocôndria (IGNEY e KRAMMER, 2002a).

A observação de que BCR-ABL estaria protegendo as células da apoptose induzida pela ausência de sinais mediados por fatores de crescimento, foi feita inicialmente em culturas primárias murinas e humanas. Em 1988, foi observado que as células de medula óssea infectadas por retrovírus e, com a construção que continha a forma p210 de BCR-ABL adquiriam uma independência a fatores de crescimento, apesar de não haver aumento na quantidade de IL-3 produzida (DALEY e BALTIMORE, 1988). Por outro lado, na linhagem hematopoética M07E, a expressão dessa isoforma, conferiu resistência a ausência de fatores de crescimento, atribuída a um mecanismo autócrina, resultando em maior secreção de fatores de crescimento, tais como IL-3 e GM-CSF (SIRARD et al., 1994). No mesmo ano, foi verificado que a capacidade de induzir o aumento de sobrevivência nas células mantidas em cultura na ausência de fatores de crescimento é, pelo menos na linhagem Ba/F3, dependente de atividade tirosina-quinase (KABAROWSKI et al., 1994).

Alguns anos mais tarde, foi sugerida a existência de uma hierarquia dose-dependente nos efeitos biológicos causados por BCR-ABL. Enquanto uma baixa expressão deste oncogene seria suficiente para proteger as células da privação de fatores de crescimento, 
apenas níveis mais elevados seriam capazes de evitar a morte celular induzida por outros estímulos apoptóticos, como, por exemplo, o tratamento com estaurosporina, um inibidor de quinases (CAMBIER et al., 1998). Apesar de pouco conhecidas, sabe-se que algumas das vias de sinalização induzidas pela atividade tirosina-quinase de BCR-ABL são semelhantes às vias desencadeadas por fatores de crescimento (SATTLER e SALGIA, 1997).

A expressão de BCR-ABL não causa apenas uma diminuição na susceptibilidade contra a ausência de fatores de crescimento, mas também contra outros estímulos apoptóticos, tais como a indução de danos no DNA, inibidores de proteínas, alterações no citoesqueleto, entre outros (BRUMATTI et al., 2003).

O estudo sobre a resistência à apoptose adquirida pelas células que expressam BCRABL ganhou importância com a verificação de que a expansão clonal na LMC se deve principalmente à inibição da morte celular e não a uma desregulação da proliferação (BEDI et al., 1994). Nesse mesmo ano, McGahon e cols., obtiveram dados que corroboraram essa idéia. Eles observaram que as células da linhagem K562 derivada de um paciente com leucemia mielóide crônica perderam a resistência a apoptose ao serem tratadas com oligonucleotídeos anti-senso específicos para $B C R-A B L$ que impediram a transcrição do oncogene (MCGAHON et al., 1994). No entanto, dados contrários foram obtidos por Gordon e cols. e Amos e cols.. Estes dois grupos não observaram nenhuma diferença na apoptose dos clones obtidos de pacientes com CML e indivíduos saudáveis (GORDON et al., 1999) (AMOS et al., 1995). Nos anos seguintes, mais trabalhos mostraram o aumento da proteção contra a apoptose, mediada por BCR-ABL, em modelos utilizando linhagens derivadas de pacientes como em células transformadas, nas quais a expressão de BCR-ABL foi induzida (CORTEZ et al., 1995; NISHII et al., 1996; AMARANTE-MENDES et al., 1998a). Atualmente, a contribuição de BCR-ABL na resistência a apoptose é mais aceita.

Cortez e cols., 1995, investigaram a participação dos motivos estruturais essenciais para o desempenho das funções deste oncogene, utilizando para tanto, construções de mutantes de BCR-ABL. A expressão de moléculas contendo apenas a substituição de um aminoácido na posição do sítio de GRB2 (Y177F), no domínio de SH2 (R552L), ou no sítio de autofosforilação do domínio de tirosina-quinase (Y793F) não causou alteração na transformação de células hematopoéticas (CORTEZ et al., 1995). No entanto, a presença simultânea destas três mutações teve grande impacto, diminuindo tanto a capacidade de 
transformação maligna destas células quanto a resistência à apoptose mediada por BCR-ABL, sugerindo que esta molécula atua em várias vias ao mesmo tempo e esta ativação concomitante é necessária para a sua habilidade de transformação e de conferir resistência à apoptose (CORTEZ et al., 1995).

Na busca pela compreensão dos mecanismos de BCR-ABL envolvidos no processo de transformação e resistência à apoptose de células hematopoéticas, alguns trabalhos focaram a investigação nos membros apoptóticos e anti-apoptóticos da família BCL-2 que atuam na mitocôndria, principal ponto de regulação da morte celular. De fato, Sanchez-Garcia e Grutz, 1995, mostraram que a expressão de BCR-ABL na linhagem hematopoética murina $\mathrm{Ba} / \mathrm{F} 3$ induzia a expressão da molécula anti-apoptótica BCL-2, tornando esta linhagem independente de fator de crescimento e capaz de formar tumores quando inoculada em camundongos. A importância de BCL-2 foi comprovada pela reversão dessas alterações fisiológicas ao incubar as células com anti-senso de BCL-2 (SANCHEZ-GARCIA e GRUTZ, 1995). Em contraste, nosso grupo de pesquisa constatou, ao introduzir o $B C R-A B L$ na linhagem humana prómielocítica HL-60, o aumento de BCL-xL, outro membro anti-apoptótico da família BCL-2, mas não de BCL-2, cuja expressão, estava inclusive diminuída em relação à linhagem infectada com o vetor vazio (AMARANTE-MENDES et al., 1998b). Dois anos depois, foi descrito que a atividade tirosina-quinase de BCR-ABL era responsável pela ativação de STAT5 que interage com o promotor de BCL-xL elevando os níveis deste gene (HORITA et al., 2000). Assim, o principal mecanismo de inibição da apoptose por BCR-ABL parece atuar ao nível mitocondrial. Nesse sentido, nosso grupo de pesquisa contribuiu para confirmação desta idéia ao mostrar que esta proteína bloqueava a liberação de citocromo c, sob diversos estímulos apoptóticos, impedindo, conseqüentemente, a ativação das caspases executoras (AMARANTE-MENDES et al., 1997b; AMARANTE-MENDES et al., 1998a; AMARANTE-MENDES et al., 1998c).

Vale ressaltar dentre outras, duas evidências que apontam para a existência de mecanismos adicionais responsáveis pela proteção contra estímulos apoptóticos. Uma delas está baseada no estudo comparativo entre as linhagens HL-60 transfectadas com os genes $B C L-2, B C L-x L$ e $B C R-A B L$, mostrando que a linhagem que expressa BCR-ABL tem uma resistência maior a diversos estímulos apoptóticos, quando comparada às células que superexpressam BCL-2 ou BCL-xL (BRUMATTI et al., 2003). A outra reside no fato de que o tratamento com anti-senso para $B C L-x L$, nas células que tiveram esse gene aumentado ao 
superexpressar $B C R-A B L$, não foi capaz de abolir a resistência conferida por esse oncogene (AMARANTE-MENDES et al., 1998b).

$\mathrm{Na}$ última década, foram descritas diversas moléculas moduladas ou alteradas por BCR-ABL que parecem contribuir com a aquisição de resistência à apoptose. Entre elas, BAD, uma proteína anti-apoptótica, que ao ser fosforilada pelas quinases AKT e RAF, se torna inativa (DEL PESO et al., 1997). Foi relatada, em 2000, a fosforilação de BAD em células hematopoéticas que expressavam BCR-ABL (NESHAT et al., 2000). Por meio do inibidor específico de PI3K e da infecção das células com retrovírus contendo construções dominante-negativas de AKT, RAF e RAS e ERK, e inibindo, portanto, a expressão dos respectivos genes, os autores mostraram que essa fosforilação ocorre de forma dependente de PI3K, AKT, RAF e RAS, mas não de ERK (NESHAT et al., 2000). Além disso, a expressão de BCR-ABL protegeu as células de expressões mais altas de BAD (NESHAT et al., 2000).

Outra molécula que parece participar do mecanismo de sobrevivência mediado por BCR-ABL é o fator de transcrição da família de reguladores de intérferon, a "interferon consensus sequence-binding protein" (ICSBP). Sua importância nas células mielóides foi inicialmente determinada em camundongos deficientes em ICBSP, uma vez que a taxa de apoptose espontânea e a sensibilidade a danos no DNA nas células desses camundongos foi menor do que em células de camundongos selvagens (GABRIELE et al., 1999). A redução da expressão deste fator de transcrição e seu efeito supressor de tumor foram verificados, um ano mais tarde, em um modelo experimental murino induzido por BCR-ABL e cuja doença se assemelha à LMC (HAO e REN, 2000).

Mais recentemente, foram descritos outros potenciais alvos de BCR-ABL. A survivina, membro da família das proteínas inibidoras de apoptose (IAP), é mais uma das moléculas com expressão aumentada por BCR-ABL. O silenciamento de sua expressão gênica torna as células BCR-ABL positivas mais susceptíveis ao tratamento com mesilato de imatinibe e estímulos apoptóticos da via mitocondrial, mas não da via extrínseca (WANG et al., 2005). Outro trabalho mostrou que a expressão da glicoproteína osteopontina (OPN) também se eleva ao induzir a expressão de BCR-ABL em células da linhagem 32D de forma dependente de tirosina-quinase, por meio da ativação da via de RAS/RAF-1/PI3K/MAPK (HICKEY et al., 2005). A proteína MCL-1, membro da família BCL-2, é mais um dos alvos de BCR-ABL cuja expressão também é induzida pela ativação da via de RAS/RAF- 
1/PI3K/MAPK, mesma via que ativa OPN (AICHBERGER et al., 2005). Além de mostrar o aumento da expressão em células CML primárias, os autores verificaram que o tratamento das células com oligonucleotídeos anti-senso específicos para MCL-1, diminui a expressão desse gene causando a inibição do crescimento e viabilidade das células de LMC (AICHBERGER et al., 2005).

É interessante destacar que a própria molécula de BCR-ABL pode promover a apoptose das células, ao ser translocada para o núcleo (VIGNERI e WANG, 2001). Nesse sentido terapias que visem a translocação podem ser uma estratégia opcional de tratamento para indução de apoptose nas células BCR-ABL positivas.

Evidências apontam para uma dependência completa da capacidade transformante deste oncogene com a sua atividade tirosina-quinase (CORTEZ et al., 1995). Entretanto, foi proposto recentemente que parte do efeito anti-apoptótico parece ser independente da atividade quinase de BCR-ABL, ou pelo menos, ocorre na ausência desta atividade e da conseqüente manutenção de substratos fosforilados em tirosina (BUENO-DA-SILVA et al., 2003).

Apesar do número de estudos realizados, ainda permanece grande a busca por alvos terapêuticos que possam ser utilizados em conjunto com os quimioterápicos já utilizados no momento, com o intuito de melhorar a eliminação das células tumorais.

Nesse sentido, as galectinas podem ser um alvo interessante por duas razões. Primeiro, a expressão de várias galectinas foi associada a uma maior agressividade em diferentes tipos de tumores sólidos. Em segundo lugar, pela interessante semelhança entre as propriedades biológicas das galectinas e as descritas para BCR-ABL.

\subsection{Galectinas}

As galectinas são proteínas solúveis pertencentes a uma família de lectinas animais. As galectinas apresentam um domínio de reconhecimento a carboidratos (CRD) com regiões de consenso conservadas e cujo sítio de ligação tem especificidade por $\beta$-galactosídeos. Os ancestrais das galectinas encontram-se presente desde fungos, esponjas e nemátodas, até mamíferos. Já foram identificados, nestes últimos organismos 15 tipos de galectinas, as quais 
apresentam distintas estruturas primárias (COOPER e BARONDES, 1999; YANG et al., 2008). Isto é, apesar de todos os membros possuírem o domínio CRD, estes possuem diferenças em sua organização.

As galectinas estão divididas em três grupos de acordo com sua estrutura e número de CRDs. Estas podem existir como monômeros ou homodímeros não covalentes de CRD (galectina-1, 2, 5, 7, 10,11, 13, 14 e 15), como quimeras compostas por um CRD ligado a um domínio diferente de lectina (galectina-3), e finalmente como repetições em série (in tandem) de dois CRDs diferentes numa única cadeia polipeptídica (galectina-4, 6, 8, 9 e 12) (HIRABAYASHI et al., 2002) (Figura 6).

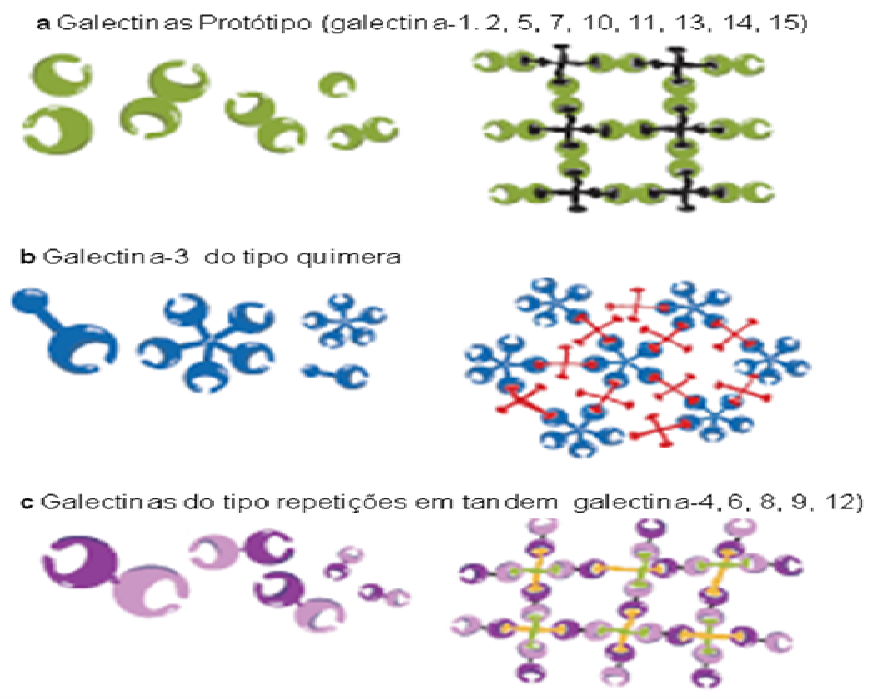

Figura 6 - Tipos de estrutura das galectinas e formação de redes entre galectinas e carboidratos multivalentes. a) Monômeros e dímeros de galectinas do tipo protótipo que possuem apenas um domínio de reconhecimento a carboidratos (CRD) do lado esquerdo, e exemplo de rede estabelecida entre galectinas (verde) e carboidratos (preto) do lado direito. b) Monômeros e pentâmeros da galectina-3, com estrutura do tipo quimera do lado esquerdo, e exemplo de rede formada entre galectina-3 (azul) e carboidratos multivalentes (vermelho). c) Monômeros de galectinas com repetições em tandem de CRDs diferentes e, portanto, com dois CRDs do lado esquerdo e um exemplo de rede formada entre esse tipo de galectina (roxo) e carboidratos (amarelo) multivalentes do lado direito.

FONTE: Adaptada de Yang R., et al., 2008.

As galectinas variam em diversos aspectos, sendo a valência dos domínios de reconhecimento a carboidratos, um deles. A maioria destas proteínas é bivalente ou multivalente. Exemplificando, as galectinas em estrutura em tandem, por possuírem dois CRD já são todas, no mínimo bivalentes. Entre aquelas do tipo protótipo, que possuem um CRD, algumas são bivalentes e a galectina-3 foi observada na forma pentamérica quando ligada a carboidratos multivalentes (AHMAD et al., 2004). Esta característica das galectinas lhes 
permite formar redes mixtas entre estas proteínas e carboidratos multivalentes (SACCHETTINI et al., 2001) (Figura 6).

A conservação destas proteínas ao longo da evolução e sua ampla distribuição nos tecidos são dois indícios de sua importância. Este fato tem sido comprovado por numerosos estudos que descreveram a sua participação em processos fisiológicos, participando da modulação da proliferação, apoptose, adesão, migração em vários tipos celulares, incluindo células do sistema imune e células tumorais (HSU e LIU, 2004).

As galectinas são sintetizadas nos ribossomos do citoplasma e desempenham funções intracelulares que diferem quando presentes no citosol ou no núcleo (LIU et al., 2002; HSU e LIU, 2004; NORLING et al., 2009). Apesar das galectinas não possuírem uma seqüência sinalizadora clássica que permite sua secreção, estas proteínas podem ser secretadas, passando a exercer outras funções, sejam extracelulares, autócrinas ou parácrinas e que dependem, por sua vez, das proteínas de superfície presentes na célula (HSU e LIU, 2004; ELOLA et al., 2007). Por um lado a capacidade de se ligar e promover o agrupamento (“cluster”) de receptores de superfície da célula, ativando esses receptores e desencadeando a sinalização intracelular assim como a de interagir com moléculas da matriz extracelular ocorre de forma dependente da ligação de carboidratos ao CRD presente nas galectinas (OCHIENG et al., 2004; HE e BAUM, 2006a; ELOLA et al., 2007; RABINOVICH et al., 2007a). Por outro lado, é interessante notar que a atuação intracelular destes tipos de lectina não parece depender da sua habilidade de se ligar a carboidratos (LIU et al., 2002; NAKAHARA e RAZ, 2006).

Destaco, nesta oportunidade, as galectinas-1 (LGALS1) e -3 (LGALS3), por serem o foco deste estudo. No entanto, a grande maioria dos resultados obtidos neste trabalho está relacionada à galectina-1 e, portanto esta molécula foi descrita com muito mais detalhe.

\subsubsection{Galectina-1 e câncer}

Em 1994, foi descrita a estrutura de dímeros de galectina-1 cristalizada que consiste em um sanduíche- $\beta$ de 22 fitas antiparalelas (BARONDES et al., 1994; LIAO et al., 1994). Assim como outras galectinas, este tipo de lectina é secretado, entretanto, o mecanismo permanece desconhecido. Um trabalho recente trouxe novas informações a esse respeito. 
Clones da linhagem CHO ("chinese hamster ovary”) que expressavam proteínas recombinantes de galectina-1, apresentando diferentes mutações pontuais na região de reconhecimento a carboidratos, tiveram a secreção desta lectina prejudicada (SEELENMEYER et al., 2005). Além disso, os autores obtiveram linhagens que expressam a forma selvagem de galectina-1, a partir do clone 13 (BRILES et al., 1977), um mutante de $\mathrm{CHO}$, cujo transportador de UDP-galactose do aparelho de Golgi é deficiente, e, portanto sem $\beta$-galactosídeos no açúcar dos receptores glicoprotéicos ou glicolipídicos de galectina-1. Neste caso, a secreção também ficou deficiente. Em conjunto, esses dados sugerem que a seqüencia alvo responsável pela secreção é o CRD e sugerem que os receptores de galectina-1 poderiam atuar de forma intracelular, participando no recrutamento das galectinas citoplasmáticas para uma via de exportação alternativa; ou extracelular, exercendo uma força que promove o transporte direcional através da membrana plasmática (SEELENMEYER et al., 2005). Este mesmo grupo demonstrou, no ano passado, ao utilizar um inibidor de formação de vesículas na membrana plasmática, que a exportação de galectina-1 não ocorria por meio da liberação dessas vesículas para o meio extracelular (SEELENMEYER et al., 2008).

Vale a pena ressaltar que devido à sua característica de ligar-se a glicoconjugados presentes na superfície celular, a função da galectina-1 varia de acordo com o repertório exposto de moléculas glicosiladas. Esta exposição, por sua vez, pode sofrer alterações segundo o estado de ativação e/ou diferenciação da célula (RABINOVICH et al., 2002). Sendo assim, essa proteína possui propriedades paradoxais que podem variar de acordo com o tipo celular, localização e/ou concentração (SCOTT e WEINBERG, 2004).

A galectina-1 possui uma vasta distribuição, encontrando-se expressa em tecidos imunoprivilegiados (RABINOVICH, 1999a; DETTIN et al., 2003; ISHIDA et al., 2003) e diferentes tipos celulares, dentre eles, células epiteliais do timo, células endoteliais, células do estroma do timo e da medula óssea, macrófagos e linfócitos $\mathrm{T} \mathrm{CD}^{+}$e T CD4 ${ }^{+}$(PERILLO et al., 1995; BLASER et al., 1998; GAUTHIER et al., 2002; HE e BAUM, 2004; BAUM e REN, 2008). Além disso, um aumento na expressão desta galectina foi observado em determinados tipos de tumores, como por exemplo, no câncer de cólon, mama, bexiga, carcinomas de ovário e de próstata (DANGUY et al., 2002). 
O acúmulo de alterações na adesão, proliferação, apoptose e migração em células normais resulta na transformação neoplásica e conseqüentemente no desenvolvimento do tumor (HANAHAN e WEINBERG, 2000). É importante ressaltar neste momento que os efeitos de algumas galectinas, dentre elas a galectina-1 e galectina-3 (descritas, respectivamente, nas seções 1.3.1 e 1.3.2), abrangem todos esses processos fisiológicos (LIU e RABINOVICH, 2005).

\subsubsection{Transformação, proliferação e apoptose}

Os mecanismos pelos quais a galectina-1 leva a transformação maligna não foram esclarecidos até o momento, mas foi relatado que esta molécula, quando presente no citoplasma, é capaz de interagir com forma oncogênica de RAS, o H-RAS dependente do CRD, já que a adição de lactose, um inibidor competitivo inespecífico de galectinas, inibe esse efeito (PAZ et al., 2001). Os autores desse estudo mostraram que a ligação de H-RASGTP à galectina-1 é essencial para a ancoragem de H-RAS na membrana celular e às atividades que dependem desta ancoragem uma vez que a superexpressão de galectina-1 aumenta o número de moléculas associadas à membrana celular assim como a transformação das células (PAZ et al., 2001). Além disso, o incremento na duração do sinal da via de RAS por meio da via RAF-1 e ERK sugerem que a ativação dessa via seria a responsável pela transformação destas células (PAZ et al., 2001) (ELAD-SFADIA et al., 2002).

Como explicado anteriormente, dados da literatura mostram que a galectina-1 pode inibir ou promover a proliferação de acordo com a sua localização na célula, tipo celular e até mesmo concentração (SCOTT e WEINBERG, 2004). Em células de glioma de rato transfectadas a galectina-1 induz a proliferação já que o uso de cDNA anti-senso para esta lectina promoveu uma parada no ciclo celular (YAMAOKA et al., 2000). Em contraposição, a exposição de células de neuroblastoma a galectina-1 exógena inibiu sua multiplicação (KOPITZ et al., 2001). Nas células tumorais de Leydig, ambos os efeitos foram observados. Em altas concentrações a galectina-1 exógena bloqueia a proliferação, enquanto baixas doses estimulam a mitose (BIRON et al., 2006).

A maioria dos trabalhos sobre galectina-1 e apoptose está concentrada nos linfócitos $\mathrm{T}$, mas alguns trabalhos relataram uma modulação da morte celular em células tumorais pela 
galectina-1. Na linhagem de câncer de próstata LNCaP, por exemplo, a transfecção destas células com o vetor contendo o gene LGALS1, resultou em bloqueio da proliferação e aumento da taxa de apoptose (ELLERHORST et al., 1999). Alguns anos mais tarde, Horiguchi e cols., observaram que a expressão de galectina-1 nas células de carcinoma de cólon, Colo201 induziu a apoptose dessas células, enquanto a adição exógena desta lectina não teve efeito. (HORIGUCHI et al., 2003).

Um dos aspectos que determina a agressividade do tumor é a formação de metástases, um processo que envolve várias etapas. Acredita-se que a seqüência de eventos fisiológicos que devem ocorrer para que ocorram as metástases envolve inicialmente o desprendimento das células do tumor primário, migração, invasão de outro tecido, sobrevivência nesse tecido, proliferação, angiogênese e escape do sistema imunológico (HANAHAN e WEINBERG, 2000; GEHO et al., 2005; PRENDERGAST e JAFFEE, 2007). É importante destacar, mais uma vez, que a galectina-1 tem participação em todos esses processos, os quais foram descritos nas seções 1.3.1.1 e 1.3.2.1.

\subsubsection{Adesão}

Alterações na adesão entre as células e entre células e matriz extracelular devem ocorrer para que as células adquiram potencial metastático, possibilitando que as células se desprendam do tecido de origem e se prendam a células endoteliais de outro tecido mais distante. De fato, foi constatada em diferentes situações uma correlação entre perda de adesão entre as células e aumento na capacidade invasiva e metastática de tumores (HOOD e CHERESH, 2002).

As galectinas são capazes de ligar-se a glicoproteínas presentes na superfície de membrana ou matriz extracelular. A galectina-1, por exemplo, se liga a laminina (ZHOU e CUMMINGS, 1993) e a proteína ligante humana MAC-2 (TINARI et al., 2001), proteínas da matriz extracelular e $\alpha 7 \beta 1$ integrina (GU et al., 1994) e $\alpha \mathrm{M} \beta 2$-integrina (AVNI et al., 1998) presentes na superfície de mioblastos e macrófagos, respectivamente. A existência dessas interações indicava que as galectinas poderiam ter algum efeito sobre a adesão intercelular e entre célula e matriz extracelular. Isto foi comprovado por estudos in vitro, ao mostrarem que galectina-1 aumenta a adesão de glicoproteínas da matriz extracelular e células de tumor de 
próstata (ELLERHORST et al., 1999) ovário (SKRINCOSKY et al., 1993) e melanoma (VAN DEN BRULE et al., 1995). Entretanto, os fatores que determinam o efeito de galectina-1 ainda não foram esclarecidos.

Em conjunto, a modulação da aderência mediada pela galectina-1, observada em estudos in vitro, assim como sua capacidade de interagir com integrinas, moléculas importantes em tumores metastático, sugerem que esta lectina poderia contribuir para a aquisição do potencial metastático.

\subsubsection{Invasão}

As células tumorais devem ser capazes de migrar para poderem invadir outros tecidos. Nesse sentido, foi constatado que a expressão de galectina-1 estava correlacionada com o grau de astrocitoma, um tipo de tumor cerebral. E, dentro dos astrocitomas com maior grau, foi detectada uma quantidade maior de galectina-1 nos pacientes que apresentavam menor sobrevida. Além disso, ao transplantar glioblastoma humanos em camundongos, houve maior presença de galectina-1 nas regiões mais invasivas desses tumores (RORIVE et al., 2001). Os autores desse estudo mostraram também que os astrócitos U373, quando incubados em placas com galectina-1 aderida, apresentavam maior mobilidade do que as células mantidas em placas sem tratamento (RORIVE et al., 2001). E, no ano seguinte, o mesmo grupo de pesquisa mostrou dois dados importantes. Primeiro, a inibição da expressão de galectina-1 endógena dos astrócitos U373 posteriormente enxertados em camundongos "nude", promoveu maior sobrevida quando comparado com os camundongos que receberam os astrócitos com expressão constitutiva de galectina-1. Segundo, os efeitos de galectina-1 na mobilidade desses

astrócitos estava relacionada com alterações na organização do citoesqueleto de actina e aumento da expressão de RhoA GTPases (CAMBY et al., 2002). Resultados semelhantes foram obtidos por Jung e cols. no ano passado, em linhagens celulares de glioblastoma multiforme humano. A expressão de galectina-1 estava positivamente correlacionada com a capacidade de migração e invasão nessas linhagens (JUNG et al., 2008). Esses estudos sugerem que a galectina-1 poderia estar envolvida com a capacidade migratória, mas são necessários mais estudos nesse campo para confirmar essa hipótese e também descobrir os mecanismos pelos quais isso ocorre. 


\subsubsection{Angiogênese}

A angiogênese, o processo de formação de novos vasos, é uma etapa crítica no crescimento de tumores sólidos. Os primeiros estudos sobre o impacto de galectina-1 na angiogênese são recentes. Inicialmente, Thijssen e cols. (2006) demonstraram a interação entre galectina-1 e anginex, um peptídeo angiostático específico, desenvolvido anteriormente por seu grupo de pesquisa. Essa interação levou os autores a investigarem a importância de galectina-1 na angiogênese. Com esse intuito, eles verificaram que o silenciamento da expressão gênica de LGALS1 inibiu tanto a proliferação como a migração de células endoteliais de cordão umbilical humano cultivadas, in vitro (THIJSSEN et al., 2006). Observaram também que o silenciamento de LGALS1, no estágio embrionário de peixeszebra, resultou no crescimento de vasos disfuncionais. Por último, mostraram que camundongos deficientes nessa proteína tiveram o crescimento de tumores prejudicado sugerindo que a galectina-1 desempenha um papel importante na angiogênese (THIJSSEN et al., 2006).

\subsubsection{Escape do sistema imune}

As células tumorais, apesar de serem próprias do organismo, expressam antígenos tumorais que podem ser reconhecidos pelas células do sistema imune, com participação de linfócitos T e B entre outras (SOGN, 1998; GRAZIANO e FINN, 2005). No entanto, embora expressem esses antígenos que podem ser reconhecidos, as células tumorais muitas vezes não ativam a resposta imune e são, de certa forma, "toleradas" pelo organismo (IGNEY e KRAMMER, 2002b; RABINOVICH et al., 2007b). São muitos os mecanismos responsáveis pelo escape da resposta imunológica de células tumorais, incluindo a eliminação de linfócitos $\mathrm{T}$ específicos, indução de sinais coestimuladores negativos e secreção de fatores imunossupressores (IGNEY e KRAMMER, 2002b; DRAKE et al., 2006).

A galectina-1 atua de variadas formas sobre as células do sistema imune. Os principais estudos, no entanto, concentram-se nos efeitos causados nos linfócitos T. De fato, no que se refere às células do sistema imune, a galectina-1, adicionada de forma exógena, parece inibir a proliferação de linfócitos T ativados (RABINOVICH et al., 1997; BLASER et al., 1998) e 
reduzir a expansão clonal de linfócitos $\mathrm{T} \mathrm{CD}^{+}$(NOVELLI et al., 1999). Em outras situações, entretanto, a galectina-1 induz a apoptose em linfócitos $\mathrm{T}$ ativados, células $\mathrm{T}$ leucêmicas e timócitos imaturos duplo negativos (PERILLO et al., 1995; PERILLO et al., 1997).

É interessante notar que as glicoproteínas identificadas como receptores de galectina1, envolvidas tanto na indução de proliferação como de apoptose são as mesmas. Entre eles podem ser destacados o CD45, CD2, CD3, CD43 e CD7 (PACE et al., 1999; PACE et al., 2000; NGUYEN et al., 2001; STILLMAN et al., 2006). Esta aparente contradição foi explicada, em parte, por dados que mostraram que o estado de glicosilação de CD45 e a ausência da enzima 2 $\beta-1,6 \mathrm{~N}$-acetilglucosaminiltransferase tornavam as células resistentes à galectina-1 exógena (NGUYEN et al., 2001). Ou seja, a glicosilação dos receptores determinaria o efeito de galectina-1 nas células. De fato, foi comprovado, em outro modelo, que o padrão de glicosilação em linfócitos T auxiliadores $\mathrm{CD}^{+}$do tipo Th1 e Th2 confere a estes dois tipos celulares, diferente susceptibilidade a apoptose (TOSCANO et al., 2007). Enquanto os linfócitos Th1 são sensíveis, os linfócitos Th2 são resistentes à apoptose mediada por galectina-1 (TOSCANO et al., 2007).

A galectina-1 também exerce um papel modulador na morte mediada pela ativação do receptor de morte FAS sensibilizando e aumentando a apoptose, respectivamente, em linfócitos T humanos "naïve" e ativados (MATARRESE et al., 2005). Neste trabalho, foram relatados alguns eventos que contribuíram para a indução de apoptose, tais como ativação das caspases -8, -9 e -3, hiperpolarização da membrana mitocondrial, liberação de citocromo c além do surgimento de brotamentos e fissões nas mitocôndrias (MATARRESE et al., 2005).

Recentemente, Brandt e cols., 2008, verificaram que a indução de apoptose mediada por galectina-1 podia ser inibida com o uso de inibidor específico de caspase- 8 ou de anticorpo monoclonal neutralizante de FAS, sugerindo que esta lectina atuaria na via de receptores de morte de indução de apoptose. Este estudo identificou pela primeira vez o FAS como alvo de galectina-1 (BRANDT et al., 2008). Fato que foi demonstrado por diferentes técnicas que compreenderam desde a marcação com imunofluorescência, indicando colocalização destas duas proteínas, como ensaio de ligação da galectina-1 ao receptor imobilizado, "immunoblotting" e até análise por espectrofotometria de massa por cromatografia-tandem líquida (BRANDT et al., 2008). 
Os eventos desencadeados pela adição de galectina-1 que induzem o processo apoptótico não estão bem estabelecidos e alguns são inclusive contraditórios. Em 2000, Rabinovich e cols. relataram a indução da atividade de ligação de DNA do fator de transcrição AP-1 e a diminuição da expressão de BCL-2 induzida pela concanavalina A, após o estímulo com galectina-1 (RABINOVICH et al., 2000). Em linfócitos B de memória, esta proteína parece inibir a fosforilação de AKT, aumentando a expressão de BIM, um membro pró-apoptótico da família BCL-2, induzindo a apoptose destas células (TABRIZI et al., 2009).

Recentemente, foi proposto por Rubinstein e cols. que a habilidade de promover apoptose em linfócitos $\mathrm{T}$ ativados corresponde a um dos mecanismos responsáveis pela evasão tumoral da resposta imune, ao verificarem que o bloqueio da expressão de galectina-1 em tumores promovia a eliminação deste tumor e o aumento de linfócitos $\mathrm{T}$ específicos a esse tumor (RUBINSTEIN et al., 2004).

Outro mecanismo que parece colaborar para a evasão do sistema imune pelas células tumorais que expressam galectina-1, nesse estudo, se refere ao desvio do balanço Th1/Th2 para um perfil Th2 da resposta imune (RUBINSTEIN et al., 2004). De fato, esse desvio foi demonstrado também em outros modelos animais de auto-imunidade e inflamação, nos quais o tratamento de camundongos com galectina-1 provoca um desvio da resposta imune para o tipo Th2 (RABINOVICH et al., 1999b; SANTUCCI et al., 2000; BAUM et al., 2003; RUBINSTEIN et al., 2004; TOSCANO et al., 2007). Pelo menos dois princípios contribuem para esse desvio, sendo um deles, a indução de apoptose preferencial dos linfócitos Th1, restando os linfócitos Th2, e o outro, a indução de aumento na produção de citocinas do perfil Th2 de forma dependente do receptor de linfócito T (TCR) (MOTRAN et al., 2008).

A galectina-1, em alguns casos, tem ainda ação antiinflamatória. Em linfócitos $\mathrm{T}$ $\mathrm{CD}^{+}$e $^{\mathrm{CD}} 8^{+}$ativados e não ativados, a adição exógena desta lectina aumenta os níveis de RNAm da citocina IL-10 e diminui IL-2 (VAN DER LEIJ et al., 2007). Em timócitos e hibridomas de linfócito $\mathrm{T}$, esta lectina causa a inibição da proliferação e produção de citocinas dependentes de IL-2 (VESPA et al., 1999), antagonizando os sinais antígeno específicos e agrupamento dependente de "rafts" lipídicos do complexo TCR/coestimulador no sítio de contato do TCR (CHUNG et al., 2000). Além disso, a galectina-1 em baixas concentrações, variando entre 0,01 e $0,1 \mu \mathrm{M}$, reduz a produção das citocinas pró-inflamatórias IFN- $\gamma$, e TNF- $\alpha$ por linfócitos T ativados (RABINOVICH et al., 1999c). Contudo, não se sabe até o 
momento se a galectina-1 expressa em tumores tem a mesma capacidade de regular a produção de citocinas, criando um ambiente antiinflamatório, quando expressa em tumores.

\subsubsection{Galectina-3 e câncer}

Esta lectina tem a particularidade de conter uma região composta de repetições em tandem de pequenos fragmentos de aminoácidos conectada ao domínio de reconhecimento a carboidrato (CRD) (HIRABAYASHI et al., 2002). Por raios-X, sua estrutura cristalizada tridimensional complexada a lactose foi definida por uma arranjo de folhas-beta de cinco fitas e seis fitas, formando um "sanduíche" similar ao de galectina-1 (SEETHARAMAN et al., 1998). É importante destacar que a galectina-3 pode ser fosforilada nos resíduos de serina 6 (Ser6) e serina 12 (Ser12) (HUFLEJT et al., 1993) e que algumas de suas funções são dependentes dessa fosforilação(YOSHII et al., 2002; TAKENAKA et al., 2004).

A seqüência sinalizadora necessária para a secreção de proteínas pelo mecanismo clássico está ausente também na galectina-3, assim como nas outras galectinas. Apesar de esse mecanismo permanecer um mistério, sabe-se apenas que o fator limitante para secreção de galectina-3 é o transporte para a membrana plasmática, pois uma vez na membrana, esta lectina é rapidamente liberada (MEHUL e HUGHES, 1997).

Com relação à distribuição de galectina-3 nos tecidos, esta é menos ampla do que de galectina-1. Sua expressão foi detectada em macrófagos (SATO e HUGHES, 1994), células epiteliais (FLOTTE et al., 1983), linfócitos T ativados (JOO et al., 2001), células NK (KOOPMAN et al., 2003) e células tumorais (DANGUY et al., 2002).

Os efeitos extracelulares e intracelulares de galectina-3 são diversos (LIU et al., 2002; OCHIENG et al., 2004). No meio extracelular, esta lectina pode oligomerizar-se na presença de carboidratos multivalentes, permitindo o "cross-linking" das glicoproteínas presentes na superfície da membrana celular, iniciando desta forma, vias de sinalização que afetam diferentes processos fisiológicos celulares (OCHIENG et al., 2004).

A expressão e correlação de galectina-3 foram descritas em diversos tipos de tumores (DANGUY et al., 2002). Em alguns casos, as células tumorais exibem um aumento em relação às células normais, como por exemplo, no câncer de fígado (HSU et al., 1999), 
tireóide (XU et al., 1995) e do sistema nervoso central (BRESALIER et al., 1997). Nesse último tipo de câncer mencionado, o aumento de galectina-3 foi inclusive associado a um maior potencial metastático (BRESALIER et al., 1997). Por outro lado, no câncer de mama, a expressão reduzida nas células tumorais, em relação às normais foi associada ao maior grau histológico (IDIKIO, 1998) e formação de metástases (CASTRONOVO et al., 1996).

\subsubsection{Transformação, proliferação e apoptose}

A importância de galectina-3 na transformação maligna foi evidenciada pelos estudos que mostraram o efeito da inibição da expressão desta lectina, em células tumorais. Tanto as células provenientes de carcinoma de mama como as de carcinoma papilar de tireóide deixaram de exibir as propriedades tumorigênicas, ao terem a expressão de galectina-3 bloqueada por anti-senso específico para esse gene (HONJO et al., 2001; YOSHII et al., 2001). Além disso, a realização do processo inverso, ou seja, a superexpressão do cDNA de galectina-3 nas células foliculares normais de tireóide resultou na indução de transformação maligna dessas células (TAKENAKA et al., 2003).

Pouco se conhece sobre o mecanismo de transformação mediado por galectina-3. Uma possibilidade foi levantada pela sua interação com proteínas da família RAS, mas principalmente o proto-oncogene K-RAS, por meio da ativação de RAF1 e PI3-K e contribuindo, portanto para a ativação das vias de sinalização e fatores de transcrição gênica (ELAD-SFADIA et al., 2004). Recentemente, o mesmo grupo de pesquisa mostrou que a molécula K-RAS.GTP recruta galectina-3 presente no citosol, para a membrana plasmática da célula, local onde se torna uma parte integrante de nanoclusters, estruturas importantes para uma transdução correta do sinal (SHALOM-FEUERSTEIN et al., 2008). Os autores mostraram que a região hidrofóbica de galectina-3 é essencial para essa interação e que o nível de galectina-3 no citosol determina a intensidade do sinal resultante da via RAS.GTP, com conseqüências na proliferação e transformação das células (SHALOM-FEUERSTEIN et al., 2008).

Por outro lado, a interação de galectina-3 com $\beta$-catenina, componente da via de sinalização mediada por WNT, e fatores de transcrição, assim como a expressão de ciclina D 
e c-MYC, sugerem que outros mecanismos de transformação podem ter a participação dessas vias ou componentes (YANG et al., 2008).

No que tange a regulação da apoptose por galectina-3, o número de estudos é maior. Esta proteína atua de forma antagônica dependendo da sua localização intracelular (núcleo ou citosol) (CALIFICE et al., 2004) ou extracelular. A indução de apoptose pela adição de galectina-3 extracelular foi descrito apenas nas linhagens Jurkat, MOLT-4 e CEM derivadas de leucemias de linfócitos T (STILLMAN et al., 2006). Por outro lado, diversos estudos indicaram que a galectina-3 endógena tem atividade anti-apoptótica (YANG et al., 2008). As primeiras evidências surgiram de estudos que constataram o ganho na resistência de células tumorais transfectadas com cDNA, evidente em diferentes tipos de tumores tratados com diversos agentes que induzem apoptose (LIU et al., 2002).

É interessante notar que após o estímulo apoptótico, ocorre a translocação de galectina-3 do citosol ou núcleo para as mitocôndrias (YU et al., 2002), bloqueando a queda do potencial de membrana, prevenindo desta forma a morte da célula, sugerindo que esta proteína poderia ter ela própria uma atividade anti-apoptótica ou poderia interagir com moléculas da mitocôndria que possuem essa atividade (MATARRESE et al., 2000).

Nesse sentido, foi estudada a estrutura de galectina-3 e descoberta uma similaridade do domínio Asp-Trp-Gly-Arg (NWGR), responsável pela regulação da apoptose, entre a galectina-3 e a proteína anti-apoptótica BCL-2 ("B-cell-lymphoma 2"), indicando que a galectina-3 poderia ter o mesmo mecanismo de regulação da apoptose de BCL-2 (YANG et al., 1996). De fato, a substituição de glicina por alanina na seqüência (NGWR), na galectina3, aboliu a sua atividade anti-apoptótica (AKAHANI et al., 1997). Entretanto, não foi comprovado ainda se o mecanismo pelo qual as duas proteínas conferem resistência à morte é o mesmo.

A regulação da apoptose pode também ser mediada por outras proteínas que interagem com galectina-3, tais como BCL-2(XU et al., 1995) e sinexina, uma proteína necessária para a prevenção da apoptose mediada pela lectina (YU et al., 2002). 


\subsubsection{Adesão, invasão, angiogênese e escape tumoral}

A importância de galectina-3 no desenvolvimento e agressividade dos tumores foi sugerida a partir da identificação de uma associação entre a expressão deste tipo de lectina e o potencial metastático dos tumores, previamente descrita na seção 1.3.2 Não somente a expressão de galectina-3 nas células tumorais (DANGUY et al., 2002), mas também no estroma têm sido associados a um potencial metastático maior e pior prognóstico (MOISA et al., 2007). Estudos em animais reforçam o papel de galectina-3 na formação de metástases, já que o tratamento de camundongos com anticorpo anti-galectina-3 (INUFUSA et al., 2001), assim como o bloqueio da capacidade de homodimerização desta proteína foram capazes de inibir o aparecimento de metástases (JOHN et al., 2003).

O papel da galectina-3 na formação de metástases pode estar relacionado com sua capacidade de modular processos de migração, invasão e angiogênese (LIU e RABINOVICH, 2005; YANG et al., 2008).

No que se refere à adesão, a alta expressão de galectina-3 em células de carcinoma com grande potencial metastático foi associada a uma adesão maior destas células quando comparadas às células normais (KHALDOYANIDI et al., 2003). Se por um lado, os efeitos da exposição de células tumorais a galectina-3 exógena sobre a motilidade e capacidade invasiva variaram de acordo com o tipo de tumor estudado (LE MARER e HUGHES, 1996; MOISA et al., 2007), por outro lado, a superexpressão endógena desta lectina em diferentes linhagens tumorais conferiu maior motilidade e capacidade invasiva a todas elas (MATARRESE et al., 2000; O'DRISCOLL et al., 2002).

Além disso, in vitro, a galectina-3 tem atividade angiogênica relacionada possivelmente a sua capacidade de induzir a migração de células endoteliais, morfologia e estimula a formação de novos tubos capilares no Matrigel contendo células endoteliais de cordão umbilical humano, tanto in vitro como in vivo (NANGIA-MAKKER et al., 2000).

Por último, a galectina-3 poderia contribuir para o desenvolvimento de tumores, induzindo a morte de linfócitos T ativados (FUKUMORI et al., 2003) ou por meio de outras formas de atuação nas células do sistema imune identificadas em outros modelos (NANGIAMAKKER et al., 2008). 


\subsection{Considerações Finais}

Este conjunto de informações mostra a importância das galectinas 1 e 3 no desenvolvimento e potencial metastático de tumores. Um grande número de trabalhos tem descrito a associação entre galectinas e câncer. Nas neoplasias, a multifuncionalidade apresentada pelas galectinas 1 e 3 parece contribuir para os processos de transformação e progressão tumoral, como resistência à apoptose, neoangiogênese, metástases e evasão da vigilância (NAKAHARA et al., 2005; RABINOVICH, 2005). Nesse sentido, principalmente as galectinas 1 e 3 vêm sendo consideradas como valiosos biomarcadores e fatores de prognóstico em diferentes linhagens tumorais e neoplasias humanas (RAZ et al., 1987; CHIARIOTTI et al., 1992; DANGUY et al., 2002). Entretanto, não existe na literatura nenhum trabalho sobre a expressão e função das galectinas 1 e 3 em tumores não sólidos. 


\section{Conclusões}

Identificamos um novo mecanismo de regulação da expressão de galectina-1, mediado pela atividade tirosina-quinase de BCR-ABL. Esta forma de regulação não é válida para galectina-3.

A galectina-1 é um potencial biomarcador de progressão tumoral e, portanto, a alta expressão desta lectina poderia ser usada, na fase avançada da LMC, como fator preditivo de pior prognóstico nesses pacientes.

A galectina-1 é um potencial candidato a alvo terapêutico na LMC, devido ao efeito cooperativo de galectina-1 e BCR-ABL na tumorigênese, observado no modelo in vivo. 


\section{Referências Bibliográficas}

ABELSON, H. T.; RABSTEIN, L. S. Lymphosarcoma: virus-induced thymic-independent disease in mice. Cancer Res.,, v.30, n.8, p.2213-22, Aug, 1970.

ADAM, J. K. et al. Immune responses in cancer. Pharmacol. Ther,, v.99, n.1, p.113-32, 2003.

AFAR, D. E. et al. Differential complementation of Bcr-Abl point mutants with c-Myc. Science.,, v.264, n.5157, p.424-6, 1994.

AGUAYO, A. et al. Angiogenesis in acute and chronic leukemias and myelodysplastic syndromes. Blood,, v.96, n.6, p.2240-5, 2000.

AHMAD, N. et al. Galectin-3 precipitates as a pentamer with synthetic multivalent carbohydrates and forms heterogeneous cross-linked complexes. J. Biol. Chem.,, v.279, n.12, p.10841-7, 2004.

AICHBERGER, K. J. et al. Identification of mcl-1 as a BCR/ABL-dependent target in chronic myeloid leukemia (CML): evidence for cooperative antileukemic effects of imatinib and mcl-1 antisense oligonucleotides. Blood,, v.105, n.8, p.3303-11, 2005.

AKAHANI, S. et al. Galectin-3: a novel antiapoptotic molecule with a functional BH1 (NWGR) domain of Bcl-2 family. Cancer Res.,, v.57, n.23, p.5272-6, 1997.

AMARANTE-MENDES, G. P. et al. Anti-apoptotic oncogenes prevent caspase-dependent and independent commitment for cell death. Cell Death Differ, v.5, n.4, p.298-306, $1998 \mathrm{c}$.

AMARANTE-MENDES, G. P.; GREEN, D. R. Abl tyrosine kinase and the control of apoptosis. In: J. Martin, S. (Ed.). Apoptosis and Cancer. Basel: Karger Landes Systems, Abl tyrosine kinase and the control of apoptosis, p.98-1151997a.

AMARANTE-MENDES, G. P.; GREEN, D. R. The regulation of apoptotic cell death. Braz. J. Med Biol. Res, v.32, n.9, p.1053-61, Sep, 1999.

AMARANTE-MENDES, G. P. et al. Bcr - Abl-mediated resistance to apoptosis is independent of PI 3-kinase activity. Cell Death Differ,, v.4, n.7, p.548-54, 1997 b.

AMARANTE-MENDES, G. P. et al. Bcl-2-independent Bcr-Abl-mediated resistance to apoptosis: protection is correlated with up regulation of Bcl-xL. Oncogene, v.16, n.11, p.1383-90, 1998b.

AMARANTE-MENDES, G. P. et al. Bcr-Abl exerts its antiapoptotic effect against diverse apoptotic stimuli through blockage of mitochondrial release of cytochrome $\mathrm{C}$ and activation of caspase-3. Blood,, v.91, n.5, p.1700-5, 1998a.

AMOS, T. A. et al. Apoptosis in chronic myeloid leukaemia: normal responses by progenitor cells to growth factor deprivation, X-irradiation and glucocorticoids. Br. J. Haematol.,, v.91, n.2, p.387-93, Oct, 1995.

ANTMAN, K. H. Introduction: the history of arsenic trioxide in cancer therapy. Oncologist, v.6 Suppl 2, p.1-2, 2001.

ARANCIA, G. et al. Cellular mechanisms of lymphocyte-mediated lysis of tumor cells. Ann. Ist Super Sanita, v.26, n.3-4, p.369-84, 1990. 
AVNI, O. et al. Complement receptor 3 of macrophages is associated with galectin-1-like protein. J. Immunol,, v.160, n.12, p.6151-8, 1998.

AZAM, M. et al. Mechanisms of autoinhibition and STI-571/imatinib resistance revealed by mutagenesis of BCR-ABL. Cell,, v.112, n.6, p.831-43, 2003.

BAIN, B. J. Diagnosis from the blood smear. N. Engl. J. Med, v.353, n.5, p.498-507, 2005.

BAINES, P. et al. Haemopoietic colony-forming cells from peripheral blood stem cell harvests: cytokine requirements and lineage potential. Br. J. Haematol,, v.88, n.3, p.472-80, 1994.

BARONDES, S. H. et al. Galectins. Structure and function of a large family of animal lectins. J. Biol. Chem.,, v.269, n.33, p.20807-10, 1994.

BARTRAM, C. R. et al. Translocation of c-abl oncogene correlates with the presence of a Philadelphia chromosome in chronic myelocytic leukaemia. Nature,, v.306, n.5940, p.277-80, Nov 17-23, 1983.

BAUM, K. J.; REN, R. Effect of Ras Inhibition in Hematopoiesis and BCR/ABL Leukemogenesis. J. Hematol. Oncol,, v.1, p.5, 2008.

BAUM, L. G. et al. Amelioration of graft versus host disease by galectin-1. Clin. Immunol, v.109, n.3, p.295-307, Dec, 2003.

BAZZONI, G. et al. Bcr/Abl expression stimulates integrin function in hematopoietic cell lines. J. Clin. Invest, v.98, n.2, p.521-8, 1996.

BECK, Z. et al. Changes in oncogene expression implicated in evolution of chronic granulocytic leukemia from its chronic phase to acceleration. Leuk. Lymphoma, v.30, n.3-4, p.293-306, 1998.

BEDI, A. et al. Inhibition of apoptosis by BCR-ABL in chronic myeloid leukemia. Blood, v.83, n.8, p.2038-44, 1994.

BENNETT, D. C. Human melanocyte senescence and melanoma susceptibility genes. Oncogene, v.22, n.20, p.3063-9, 2003.

BENVENUTO, G. et al. Cell-specific transcriptional regulation and reactivation of galectin-1 gene expression are controlled by DNA methylation of the promoter region. Mol. Cell Biol.,, v.16, n.6, p.2736-43, Jun, 1996.

BHATIA, R. et al. Treatment of marrow stroma with interferon-alpha restores normal beta 1 integrin-dependent adhesion of chronic myelogenous leukemia hematopoietic progenitors. Role of MIP-1 alpha. J. Clin. Invest,, v.96, n.2, p.931-9, 1995.

BIRON, V. A. et al. Galectin-1: biphasic growth regulation of Leydig tumor cells. Glycobiology,, v.16, n.9, p.810-21, 2006.

BLALOCK, W. L. et al. Signal transduction, cell cycle regulatory, and anti-apoptotic pathways regulated by IL-3 in hematopoietic cells: possible sites for intervention with antineoplastic drugs. Leukemia,, v.13, n.8, p.1109-66, 1999.

BLASER, C. et al. Beta-galactoside-binding protein secreted by activated $\mathrm{T}$ cells inhibits antigen-induced proliferation of T cells. Eur. J. Immunol, v.28, n.8, p.2311-9, 1998.

BODEY, G. P. et al. Fever and infection in leukemic patients: a study of 494 consecutive patients. Cancer,, v.41, n.4, p.1610-22, 1978. 
BODNAR, A. G. et al. Extension of life-span by introduction of telomerase into normal human cells. Science,, v.279, n.5349, p.349-52, Jan 16, 1998.

BOGUSKI, M. S.; MCCORMICK, F. Proteins regulating Ras and its relatives. Nature,, v.366, n.6456, p.643-54, Dec 16, 1993.

BONIFAZI, F. et al. Chronic myeloid leukemia and interferon-alpha: a study of complete cytogenetic responders. Blood,, v.98, n.10, p.3074-81, Nov 15, 2001.

BOYUM, A. Isolation of lymphocytes, granulocytes and macrophages. Scand. J. Immunol,, v.Suppl 5, p.9-15, Jun, 1976.

BRANDT, B. et al. Galectin-1 induced activation of the apoptotic death-receptor pathway in human Jurkat T lymphocytes. Histochem. Cell Biol.,, v.129, n.5, p.599-609, May, 2008.

BRASHER, B. B. et al. Mutational analysis of the regulatory function of the c-Abl Src homology 3 domain. Oncogene,, v.20, n.53, p.7744-52, Nov 22, 2001.

BRASHER, B. B.; VAN ETTEN, R. A. c-Abl has high intrinsic tyrosine kinase activity that is stimulated by mutation of the Src homology 3 domain and by autophosphorylation at two distinct regulatory tyrosines. J. Biol. Chem.,, v.275, n.45, p.35631-7, Nov 10, 2000.

BRASIL. Organização mundial da Saúde. Estimativas 2008: Incidência de Câncer no Brasil. Rio de Janeiro: INCA, 2007.

BRESALIER, R. S. et al. Expression of the endogenous galactose-binding protein galectin-3 correlates with the malignant potential of tumors in the central nervous system. Cancer,, v.80, n.4, p.776-87, Aug 15, 1997.

BRILES, E. B. et al. Isolation of wheat germ agglutinin-resistant clones of Chinese hamster ovary cells deficient in membrane sialic acid and galactose. J. Biol. Chem.,, v.252, n.3, p.1107-16, Feb 10, 1977.

BRINCKER, H. Population-based age- and sex-specific incidence rates in the 4 main types of leukaemia. Scand. J. Haematol,, v.29, n.3, p.241-9, Sep, 1982.

BRUMATTI, G. et al. Comparison of the anti-apoptotic effects of Bcr-Abl, Bcl-2 and Bclx(L) following diverse apoptogenic stimuli. FEBS Lett, v.541, n.1-3, p.57-63, Apr 24, 2003.

BUCHDUNGER, E. et al. Abl protein-tyrosine kinase inhibitor STI571 inhibits in vitro signal transduction mediated by c-kit and platelet-derived growth factor receptors. J. Pharmacol. Exp. Ther, v.295, n.1, p.139-45, Oct, 2000.

BUENO-DA-SILVA, A. E. et al. Bcr-Abl-mediated resistance to apoptosis is independent of constant tyrosine-kinase activity. Cell Death Differ,, v.10, n.5, p.592-8, May, 2003.

BURGER, O. et al. Placental protein 13 (PP-13): effects on cultured trophoblasts, and its detection in human body fluids in normal and pathological pregnancies. Placenta, v.25, n.7, p.608-22, Aug, 2004.

CAHILL, M. A. et al. Signalling pathways: jack of all cascades. Curr. Biol.,, v.6, n.1, p.16-9, Jan 1, 1996.

CALDWELL, S. A. et al. The Fas/Fas ligand pathway is important for optimal tumor regression in a mouse model of CTL adoptive immunotherapy of experimental CMS4 lung metastases. J Immunol,, v.171, n.5, p.2402-12, Sep 1, 2003. 
CALIFICE, S. et al. Dual activities of galectin-3 in human prostate cancer: tumor suppression of nuclear galectin-3 vs tumor promotion of cytoplasmic galectin-3. Oncogene,, v.23, n.45, p.7527-36, Sep 30, 2004.

CAMBIER, N. et al. BCR-ABL activates pathways mediating cytokine independence and protection against apoptosis in murine hematopoietic cells in a dose-dependent manner. Oncogene,, v.16, n.3, p.335-48, Jan 22, 1998.

CAMBY, I. et al. Galectin-1 modulates human glioblastoma cell migration into the brain through modifications to the actin cytoskeleton and levels of expression of small GTPases. J. Neuropathol. Exp. Neurol,, v.61, n.7, p.585-96, Jul, 2002.

CAMPISI, J. Cancer, aging and cellular senescence. In Vivo, v.14, n.1, p.183-8, Jan-Feb, 2000.

CAMPISI, J. Cellular senescence as a tumor-suppressor mechanism. Trends Cell Biol.,, v.11, n.11, p.S27-31, Nov, 2001.

CANITROT, Y. et al. p210 BCR/ABL kinase regulates nucleotide excision repair (NER) and resistance to UV radiation. Blood,, v.102, n.7, p.2632-7, Oct 1, 2003.

CARTER, T. A. et al. Inhibition of drug-resistant mutants of ABL, KIT, and EGF receptor kinases. Proc. Natl. Acad. Sci. U S A,, v.102, n.31, p.11011-6, Aug 2, 2005.

CASTRONOVO, V. et al. Decreased expression of galectin-3 is associated with progression of human breast cancer. J. Pathol,, v.179, n.1, p.43-8, May, 1996.

CERVANTES, F. et al. 'Lymphoid' blast crisis of chronic myeloid leukaemia is associated with distinct clinicohaematological features. Br. J. Haematol, v.100, n.1, p.123-8, Jan, 1998.

CHAI, S. K. et al. Constitutive activation of JAKs and STATs in BCR-Abl-expressing cell lines and peripheral blood cells derived from leukemic patients. J. Immunol, v.159, n.10, p.4720-8, Nov 15, 1997.

CHAKRABORTY, M. et al. Irradiation of tumor cells up-regulates Fas and enhances CTL lytic activity and CTL adoptive immunotherapy. J. Immunol, v.170, n.12, p.6338-47, Jun 15, 2003.

CHANG, J. S. et al. High levels of the BCR/ABL oncoprotein are required for the MAPKhnRNP-E2 dependent suppression of C/EBPalpha-driven myeloid differentiation. Blood, v.110, n.3, p.994-1003, Aug 1, 2007.

CHEN, Q. et al. Oxidative DNA damage and senescence of human diploid fibroblast cells. Proc. Natl. Acad. Sci. U S A, v.92, n.10, p.4337-41, May 9, 1995.

CHEN, S. J. et al. Philadelphia-positive acute leukemia: lineage promiscuity and inconsistently rearranged breakpoint cluster region. Leukemia,, v.2, n.5, p.261-73, May, 1988.

CHIARIOTTI, L. et al. Activation of the galectin-1 (L-14-I) gene from nonexpressing differentiated cells by fusion with undifferentiated and tumorigenic cells. Cell Growth Differ, v.5, n.7, p.769-75, Jul, 1994.

CHIARIOTTI, L. et al. Expression of galectin-1 in normal human thyroid gland and in differentiated and poorly differentiated thyroid tumors. Int. J. Cancer,, v.64, n.3, p.171-5, Jun 22, 1995. 
CHIARIOTTI, L. et al. Increased expression of the negative growth factor, galactosidebinding protein, gene in transformed thyroid cells and in human thyroid carcinomas. Oncogene,, v.7, n.12, p.2507-11, Dec, 1992.

CHISSOE, S. L. et al. Sequence and analysis of the human ABL gene, the BCR gene, and regions involved in the Philadelphia chromosomal translocation. Genomics, v.27, n.1, p.6782, May $1,1995$.

CHRONIC MYELOID LEUKEMIA TRIALISTS' COLLABORATIVE GROUP. Interferon alfa versus chemotherapy for chronic myeloid leukemia: a meta-analysis of seven randomized trials: Chronic Myeloid Leukemia Trialists' Collaborative Group. v.89, 1616-20 p., 1997

CHUNG, C. D. et al. Galectin-1 induces partial TCR zeta-chain phosphorylation and antagonizes processive TCR signal transduction. J. Immunol,, v.165, n.7, p.3722-9, Oct 1, 2000 .

CINDOLO, L. et al. Galectin-1 and galectin-3 expression in human bladder transitional-cell carcinomas. Int. J. Cancer,, v.84, n.1, p.39-43, Feb 19, 1999.

CLARK, S. S. et al. Expression of a distinctive BCR-ABL oncogene in Ph1-positive acute lymphocytic leukemia (ALL). Science,, v.239, n.4841 Pt 1, p.775-7, Feb 12, 1988.

CLEVELAND, J. L. et al. Tyrosine kinase oncogenes abrogate interleukin-3 dependence of murine myeloid cells through signaling pathways involving c-myc: conditional regulation of c-myc transcription by temperature-sensitive v-abl. Mol. Cell Biol.,, v.9, n.12, p.5685-95, Dec, 1989.

COHEN, L. et al. Transcriptional activation of a ras-like gene (kir) by oncogenic tyrosine kinases. Proc. Natl. Acad. Sci. U S A,, v.91, n.26, p.12448-52, Dec 20, 1994.

COOPER, D. N.; BARONDES, S. H. God must love galectins; he made so many of them. Glycobiology,, v.9, n.10, p.979-84, Oct, 1999.

CORBIN, A. S. et al. Analysis of the structural basis of specificity of inhibition of the Abl kinase by STI571. J. Biol. Chem.,, v.277, n.35, p.32214-9, Aug 30, 2002.

CORSO, A. et al. Chronic myelogenous leukemia and exposure to ionizing radiation--a retrospective study of 443 patients. Ann. Hematol, v.70, n.2, p.79-82, Feb, 1995.

CORTES, J.; KANTARJIAN, H. Advanced-phase chronic myeloid leukemia. Semin. Hematol,, v.40, n.1, p.79-86, Jan, 2003a.

CORTES, J. et al. Effects of age on prognosis with imatinib mesylate therapy for patients with Philadelphia chromosome-positive chronic myelogenous leukemia. Cancer,, v.98, n.6, p.1105-13, Sep 15, 2003b.

CORTES, J. E. et al. Chronic myelogenous leukemia: a review. Am. J. Med, v.100, n.5, p.555-70, May, 1996.

CORTES, J. E. et al. Staging of chronic myeloid leukemia in the imatinib era: an evaluation of the World Health Organization proposal. Cancer,, v.106, n.6, p.1306-15, Mar 15, 2006.

CORTEZ, D. et al. Structural and signaling requirements for BCR-ABL-mediated transformation and inhibition of apoptosis. Mol. Cell Biol.,, v.15, n.10, p.5531-41, Oct, 1995.

COURAUD, P. O. et al. Molecular cloning, characterization, and expression of a human 14kDa lectin. J. Biol. Chem.,, v.264, n.2, p.1310-6, Jan 15, 1989. 
DALEY, G. Q.; BALTIMORE, D. Transformation of an interleukin 3-dependent hematopoietic cell line by the chronic myelogenous leukemia-specific P210bcr/abl protein. Proc. Natl. Acad. Sci. U S A, v.85, n.23, p.9312-6, Dec, 1988.

DANGUY, A. et al. Galectins and cancer. Biochim. Biophys. Acta,, v.1572, n.2-3, p.285-93, 2002.

DANNENBERG, J. H. et al. Ablation of the retinoblastoma gene family deregulates $G(1)$ control causing immortalization and increased cell turnover under growth-restricting conditions. Genes Dev,, v.14, n.23, p.3051-64, Dec 1, 2000.

DAVIS, J. E. et al. Granzyme A and B-deficient killer lymphocytes are defective in eliciting DNA fragmentation but retain potent in vivo anti-tumor capacity. Eur. J. Immunol, v.31, n.1, p.39-47, Jan, 2001.

DE GREGORIO, E. et al. The overlap of Inr and TATA elements sets the use of alternative transcriptional start sites in the mouse galectin-1 gene promoter. Gene,, v.268, n.1-2, p.21523, May 2, 2001.

DE GROOT, R. P. et al. STAT5 activation by BCR-Abl contributes to transformation of K562 leukemia cells. Blood,, v.94, n.3, p.1108-12, Aug 1, 1999.

DEININGER, M. W. et al. Selective induction of leukemia-associated fusion genes by highdose ionizing radiation. Cancer Res,, v.58, n.3, p.421-5, Feb 1, 1998.

DEININGER, M. W. et al. The tyrosine kinase inhibitor CGP57148B selectively inhibits the growth of BCR-ABL-positive cells. Blood,, v.90, n.9, p.3691-8, Nov 1, 1997.

DEININGER, M. W. et al. The molecular biology of chronic myeloid leukemia. Blood, v.96, n.10, p.3343-56, Nov 15, 2000a.

DEININGER, M. W. et al. BCR-ABL tyrosine kinase activity regulates the expression of multiple genes implicated in the pathogenesis of chronic myeloid leukemia. Cancer Res, v.60, n.7, p.2049-55, Apr 1, 2000 b.

DEL PESO, L. et al. Interleukin-3-induced phosphorylation of BAD through the protein kinase Akt. Science,, v.278, n.5338, p.687-9, Oct 24, 1997.

DETTIN, L. et al. Regulated expression and ultrastructural localization of galectin-1, a proapoptotic beta-galactoside-binding lectin, during spermatogenesis in rat testis. Biol. Reprod,, v.68, n.1, p.51-9, Jan, 2003.

DIAS-BARUFFI, M. et al. Dimeric galectin-1 induces surface exposure of phosphatidylserine and phagocytic recognition of leukocytes without inducing apoptosis. J. Biol. Chem.,, v.278, n.42, p.41282-93, Oct 17, 2003.

DIEKMANN, D. et al. Bcr encodes a GTPase-activating protein for p21rac. Nature, v.351, n.6325, p.400-2, May 30, 1991.

DIMRI, G. P. et al. Regulation of a senescence checkpoint response by the E2F1 transcription factor and p14(ARF) tumor suppressor. Mol. Cell Biol,, v.20, n.1, p.273-85, Jan, 2000.

DOREY, K. et al. Phosphorylation and structure-based functional studies reveal a positive and a negative role for the activation loop of the c-Abl tyrosine kinase. Oncogene, v.20, n.56, p.8075-84, Dec 6, 2001.

DRAKE, C. G. et al. Mechanisms of immune evasion by tumors. Adv. Immunol, v.90, p.5181, 2006. 
DREYFUSS, G. et al. hnRNP proteins and the biogenesis of mRNA. Annu. Rev. Biochem., v.62, p.289-321, 1993.

DRUKER, B. J. et al. Efficacy and safety of a specific inhibitor of the BCR-ABL tyrosine kinase in chronic myeloid leukemia. N. Engl. J. Med,, v.344, n.14, p.1031-7, Apr 5, 2001.

DRUKER, B. J. et al. Effects of a selective inhibitor of the Abl tyrosine kinase on the growth of Bcr-Abl positive cells. Nat. Med,, v.2, n.5, p.561-6, May, 1996.

ELAD-SFADIA, G. et al. Galectin-3 augments K-Ras activation and triggers a Ras signal that attenuates ERK but not phosphoinositide 3-kinase activity. J. Biol. Chem.,, v.279, n.33, p.34922-30, Aug 13, 2004.

ELAD-SFADIA, G. et al. Galectin-1 augments Ras activation and diverts Ras signals to Raf-1 at the expense of phosphoinositide 3-kinase. J. Biol. Chem., v.277, n.40, p.37169-75, Oct 4, 2002.

ELLERHORST, J. et al. Galectin-1 and galectin-3 expression in human prostate tissue and prostate cancer. Urol Res,, v.27, n.5, p.362-7, Oct, 1999.

ELLIS, R. E. et al. Mechanisms and functions of cell death. Annu. Rev. Cell Biol,, v.7, p.66398, 1991.

ELOLA, M. T. et al. Galectins: matricellular glycan-binding proteins linking cell adhesion, migration, and survival. Cell. Mol. Life Sci,, v.64, n.13, p.1679-700, Jul, 2007.

ERNST, T. J. et al. p210Bcr/Abl and p160v-Abl induce an increase in the tyrosine phosphorylation of p93c-Fes. J. Biol. Chem.,, v.269, n.8, p.5764-9, Feb 25, 1994.

FADERL, S. et al. The biology of chronic myeloid leukemia. N. Engl. J. Med, v.341, n.3, p.164-72, Jul 15, 1999.

FLOTTE, T. J. et al. Dendritic cell and macrophage staining by monoclonal antibodies in tissue sections and epidermal sheets. Am. J. Pathol,, v.111, n.1, p.112-24, Apr, 1983.

FOLLEY, J. H. et al. Incidence of leukemia in survivors of the atomic bomb in Hiroshima and Nagasaki, Japan. Am. J. Med,, v.13, n.3, p.311-21, Sep, 1952.

FONTANA, S. et al. Comparative proteome profiling and functional analysis of chronic myelogenous leukemia cell lines. J. Proteome Res,, v.6, n.11, p.4330-42, Nov, 2007.

FUERTES, M. B. et al. Regulated expression of galectin-1 during T-cell activation involves Lck and Fyn kinases and signaling through MEK1/ERK, p38 MAP kinase and p70S6 kinase. Mol. Cell Biochem.,, v.267, n.1-2, p.177-85, Dec, 2004.

FUKUMORI, T. et al. CD29 and CD7 mediate galectin-3-induced type II T-cell apoptosis. Cancer Res,, v.63, n.23, p.8302-11, Dec 1, 2003.

FURSTOSS, O. et al. c-Abl is an effector of Src for growth factor-induced c-myc expression and DNA synthesis. Embo J,, v.21, n.4, p.514-24, Feb 15, 2002.

GABIUS, H. J. et al. Localization of endogenous lectins in normal human breast, benign breast lesions and mammary carcinomas. Virchows Arch. B Cell Pathol. Incl. Mol. Pathol,, v.52, n.2, p.107-15, 1986.

GABRIELE, L. et al. Regulation of apoptosis in myeloid cells by interferon consensus sequence-binding protein. J. Exp. Med,, v.190, n.3, p.411-21, Aug 2, 1999. 
GALE, R. P. et al. Immune therapy of chronic myelogenous leukemia. Leuk. Res,, v.29, n.5, p.583-6, May, 2005.

GARCIA, R.; JOVE, R. Activation of STAT transcription factors in oncogenic tyrosine kinase signaling. J. Biomed. Sci, v.5, n.2, p.79-85, 1998.

GARIN, M. I. et al. Galectin-1: a key effector of regulation mediated by CD4+CD25+ T cells. Blood,, v.109, n.5, p.2058-65, Mar 1, 2007.

GAUTHIER, L. et al. Galectin-1 is a stromal cell ligand of the pre-B cell receptor (BCR) implicated in synapse formation between pre-B and stromal cells and in pre-BCR triggering. Proc. Natl. Acad. Sci U S A,, v.99, n.20, p.13014-9, Oct 1, 2002.

GEHO, D. H. et al. Physiological mechanisms of tumor-cell invasion and migration. Physiology (Bethesda), v.20, p.194-200, Jun, 2005.

GERBER, H. P. et al. VEGF regulates haematopoietic stem cell survival by an internal autocrine loop mechanism. Nature,, v.417, n.6892, p.954-8, Jun 27, 2002.

GILES, F. J. et al. Phase I and pharmacokinetic study of DX-8951f (exatecan mesylate), a hexacyclic camptothecin, on a daily-times-five schedule in patients with advanced leukemia. Clin. Cancer Res,, v.8, n.7, p.2134-41, Jul, 2002.

GIRALT, S. et al. CD8-depleted donor lymphocyte infusion as treatment for relapsed chronic myelogenous leukemia after allogeneic bone marrow transplantation. Blood, v.86, n.11, p.4337-43, Dec 1, 1995.

GITT, M. A.; BARONDES, S. H. Genomic sequence and organization of two members of a human lectin gene family. Biochemistry,, v.30, n.1, p.82-9, Jan 8, 1991.

GORDON, M. Y. et al. Cell biology of CML cells. Leukemia,, v.13 Suppl 1, p.S65-71, Apr, 1999.

GORDON, M. Y. et al. Altered adhesive interactions with marrow stroma of haematopoietic progenitor cells in chronic myeloid leukaemia. Nature,, v.328, n.6128, p.342-4, Jul 23-29, 1987.

GOTOH, A. et al. Tyrosine phosphorylation and activation of focal adhesion kinase (p125FAK) by BCR-ABL oncoprotein. Exp. Hematol,, v.23, n.11, p.1153-9, Oct, 1995.

GRAZIANO, D. F.; FINN, O. J. Tumor antigens and tumor antigen discovery. Cancer Treat. Res,, v.123, p.89-111, 2005.

GREEN, D. R.; AMARANTE-MENDES, G. P. The point of no return: mitochondria, caspases, and the commitment to cell death. Results Probl. Cell Differ,, v.24, p.45-61, 1998.

GRIFFITHS, G. M.; ARGON, Y. Structure and biogenesis of lytic granules. Curr. Top. Microbiol Immunol,, v.198, p.39-58, 1995.

GROFFEN, J. et al. Philadelphia Chromosome Translocation. In: A. B. Deisseroth e R. B. Arlinghaus (Ed.). Chronic myelogenous leukemia : molecular approaches to research and therapy. New York: Dekker, Philadelphia Chromosome Translocation, p.181-2091991.

GROFFEN, J. et al. Philadelphia chromosomal breakpoints are clustered within a limited region, bcr, on chromosome 22. Cell,, v.36, n.1, p.93-9, Jan, 1984. 
GU, M. et al. Selective modulation of the interaction of alpha 7 beta 1 integrin with fibronectin and laminin by L-14 lectin during skeletal muscle differentiation. J. Cell. Sci,, v.107 ( Pt 1), p.175-81, Jan, 1994.

HAHN, E. A. et al. Quality of life in patients with newly diagnosed chronic phase chronic myeloid leukemia on imatinib versus interferon alfa plus low-dose cytarabine: results from the IRIS Study. J. Clin. Oncol,, v.21, n.11, p.2138-46, Jun 1, 2003.

HANAHAN, D.; WEINBERG, R. A. The hallmarks of cancer. Cell, v.100, n.1, p.57-70, Jan $7,2000$.

HANTSCHEL, O.; SUPERTI-FURGA, G. Regulation of the c-Abl and Bcr-Abl tyrosine kinases. Nat. Rev. Mol. Cell. Biol,, v.5, n.1, p.33-44, Jan, 2004.

HAO, S. X.; REN, R. Expression of interferon consensus sequence binding protein (ICSBP) is downregulated in Bcr-Abl-induced murine chronic myelogenous leukemia-like disease, and forced coexpression of ICSBP inhibits Bcr-Abl-induced myeloproliferative disorder. Mol. Cell. Biol,, v.20, n.4, p.1149-61, Feb, 2000.

HARRIS, S. L.; LEVINE, A. J. The p53 pathway: positive and negative feedback loops. Oncogene,, v.24, n.17, p.2899-908, Apr 18, 2005.

HARVEY, D. M.; LEVINE, A. J. p53 alteration is a common event in the spontaneous immortalization of primary BALB/c murine embryo fibroblasts. Genes Dev,, v.5, n.12B, p.2375-85, Dec, 1991.

HAYFLICK, L.; MOORHEAD, P. S. The serial cultivation of human diploid cell strains. Exp. Cell. Res,, v.25, p.585-621, Dec, 1961.

HE, J.; BAUM, L. G. Presentation of galectin-1 by extracellular matrix triggers T cell death. J. Biol. Chem.,, v.279, n.6, p.4705-12, Feb 6, 2004.

HE, J.; BAUM, L. G. Galectin interactions with extracellular matrix and effects on cellular function. Methods Enzymol,, v.417, p.247-56, 2006a.

HEANEY, C. et al. Direct binding of CRKL to BCR-ABL is not required for BCR-ABL transformation. Blood, v.89, n.1, p.297-306, Jan 1, 1997.

HEHLMANN, R. et al. Chronic myeloid leukemia: a model for oncology. Ann. Hematol, v.84, n.8, p.487-97, Aug, 2005.

HEHLMANN, R. et al. Randomized comparison of interferon-alpha with busulfan and hydroxyurea in chronic myelogenous leukemia. The German CML Study Group. Blood,, v.84, n.12, p.4064-77, Dec 15, 1994.

HELGASON, C. D. et al. Targeted disruption of SHIP leads to hemopoietic perturbations, lung pathology, and a shortened life span. Genes Dev, v.12, n.11, p.1610-20, Jun 1, 1998.

HENKART, P. A. Lymphocyte-mediated cytotoxicity: two pathways and multiple effector molecules. Immunity, v.1, n.5, p.343-6, Aug, 1994a.

HENKART, P. A.; SITKOVSKY, M. V. Cytotoxic lymphocytes. Two ways to kill target cells. Curr. Biol,, v.4, n.10, p.923-5, Oct 1, 1994b.

HICKEY, F. B. et al. Bcr-Abl regulates osteopontin transcription via Ras, PI-3K, aPKC, Raf1, and MEK. J Leukoc Biol,, v.78, n.1, p.289-300, Jul, 2005. 
HIRABAYASHI, J. et al. Oligosaccharide specificity of galectins: a search by frontal affinity chromatography. Biochim. Biophis. Acta,, v.1572, n.2-3, p.232-54, Sep 19, 2002.

HOCHHAUS, A. et al. Molecular and chromosomal mechanisms of resistance to imatinib (STI571) therapy. Leukemia,, v.16, n.11, p.2190-6, Nov, 2002.

HONJO, Y. et al. Down-regulation of galectin-3 suppresses tumorigenicity of human breast carcinoma cells. Clin. Cancer Res,, v.7, n.3, p.661-8, Mar, 2001.

HOOD, J. D.; CHERESH, D. A. Role of integrins in cell invasion and migration. Nat. Rev. Cancer,, v.2, n.2, p.91-100, Feb, 2002.

HOOVER, R. R. et al. Overcoming STI571 resistance with the farnesyl transferase inhibitor SCH66336. Blood, v.100, n.3, p.1068-71, Aug 1, 2002.

HORIGUCHI, N. et al. Galectin-1 induces cell adhesion to the extracellular matrix and apoptosis of non-adherent human colon cancer Colo201 cells. J. Biochem.,, v.134, n.6, p.86974, Dec, 2003.

HORITA, M. et al. Blockade of the Bcr-Abl kinase activity induces apoptosis of chronic myelogenous leukemia cells by suppressing signal transducer and activator of transcription 5dependent expression of Bcl-xL. J. Exp. Med,, v.191, n.6, p.977-84, Mar 20, 2000.

HSU, D. K. et al. Galectin-3 expression is induced in cirrhotic liver and hepatocellular carcinoma. Int. J. Cancer, v.81, n.4, p.519-26, May 17, 1999.

HSU, D. K.; LIU, F. T. Regulation of cellular homeostasis by galectins. Glycoconj. J, v.19, n.7-9, p.507-15, 2004.

HU, Y. et al. Requirement of Src kinases Lyn, Hck and Fgr for BCR-ABL1-induced Blymphoblastic leukemia but not chronic myeloid leukemia. Nat. Genet,, v.36, n.5, p.453-61, May, 2004.

HUESKEN, D. et al. Design of a genome-wide siRNA library using an artificial neural network. Nat. Biotechnol,, v.23, n.8, p.995-1001, Aug, 2005.

HUFLEJT, M. E. et al. L-29, a soluble lactose-binding lectin, is phosphorylated on serine 6 and serine 12 in vivo and by casein kinase I. J. Biol. Chem.,, v.268, n.35, p.26712-8, Dec 15, 1993.

HUNTLY, B. J. et al. Deletions of the derivative chromosome 9 occur at the time of the Philadelphia translocation and provide a powerful and independent prognostic indicator in chronic myeloid leukemia. Blood,, v.98, n.6, p.1732-8, Sep 15, 2001.

HURLEY, R. W. et al. Direct adhesion to bone marrow stroma via fibronectin receptors inhibits hematopoietic progenitor proliferation. J. Clin. Invest,, v.96, n.1, p.511-9, Jul, 1995.

IDIKIO, H. Galectin-3 expression in human breast carcinoma: correlation with cancer histologic grade. Int. J. Oncol, v.12, n.6, p.1287-90, Jun, 1998.

IERVOLINO, A. et al. hnRNP A1 nucleocytoplasmic shuttling activity is required for normal myelopoiesis and BCR/ABL leukemogenesis. Mol. Cell. Biol,, v.22, n.7, p.2255-66, Apr, 2002.

IGNEY, F. H.; KRAMMER, P. H. Death and anti-death: tumour resistance to apoptosis. Nat. Rev Cancer,, v.2, n.4, p.277-88, Apr, 2002a. 
IGNEY, F. H.; KRAMMER, P. H. Immune escape of tumors: apoptosis resistance and tumor counterattack. J. Leukoc. Biol,, v.71, n.6, p.907-20, Jun, 2002 b.

INUFUSA, H. et al. Role of galectin-3 in adenocarcinoma liver metastasis. Int. J. Oncol,, v.19, n.5, p.913-9, Nov, 2001.

ISHIDA, K. et al. Participation of pigment epithelium in ocular immune privilege. 3. Epithelia cultured from iris, ciliary body, and retina suppress T-cell activation by partially nonoverlapping mechanisms. Ocul. Immunol. Inflamm,, v.11, n.2, p.91-105, Jun, 2003.

JIN, A. et al. BCR/ABL and IL-3 activate Rap1 to stimulate the B-Raf/MEK/Erk and Akt signaling pathways and to regulate proliferation, apoptosis, and adhesion. Oncogene, v.25, n.31, p.4332-40, Jul 20, 2006.

JOHANSSON, B. et al. Cytogenetic and molecular genetic evolution of chronic myeloid leukemia. Acta Haematol,, v.107, n.2, p.76-94, 2002.

JOHN, C. M. et al. Truncated galectin-3 inhibits tumor growth and metastasis in orthotopic nude mouse model of human breast cancer. Clin. Cancer Res,, v.9, n.6, p.2374-83, Jun, 2003.

JONASCH, E.; HALUSKA, F. G. Interferon in oncological practice: review of interferon biology, clinical applications, and toxicities. Oncologist,, v.6, n.1, p.34-55, 2001.

JOO, H. G. et al. Expression and function of galectin-3, a beta-galactoside-binding protein in activated T lymphocytes. J. Leukoc. Biol,, v.69, n.4, p.555-64, Apr, 2001.

JUNG, T. Y. et al. Role of galectin-1 in migration and invasion of human glioblastoma multiforme cell lines. J. Neurosurg,, v.109, n.2, p.273-84, Aug, 2008.

KABAROWSKI, J. H. et al. A temperature sensitive p210 BCR-ABL mutant defines the primary consequences of BCR-ABL tyrosine kinase expression in growth factor dependent cells. Embo J,, v.13, n.24, p.5887-95, Dec 15, 1994.

KAFROUNI, M. I. et al. The role of TNF-TNFR2 interactions in generation of CTL responses and clearance of hepatic adenovirus infection. J. Leukoc. Biol,, v.74, n.4, p.564-71, Oct, 2003.

KAGI, D. et al. Fas and perforin pathways as major mechanisms of $\mathrm{T}$ cell-mediated cytotoxicity. Science, , v.265, n.5171, p.528-30, Jul 22, 1994.

KAMIJO, T. et al. Loss of the ARF tumor suppressor reverses premature replicative arrest but not radiation hypersensitivity arising from disabled atm function. Cancer Res,, v.59, n.10, p.2464-9, May 15, 1999.

KANTARJIAN, H. et al. The MD Anderson manual of medical oncology. New York: McGraw-Hill Medical Pub. Division, xviii, 2006. 1149 p.p.

KANTARJIAN, H. et al. Hematologic and cytogenetic responses to imatinib mesylate in chronic myelogenous leukemia. N. Engl. J. Med, v.346, n.9, p.645-52, Feb 28, 2002a.

KANTARJIAN, H. M. et al. Chronic myelogenous leukemia: a concise update. Blood, v.82, n.3, p.691-703, Aug 1, 1993.

KANTARJIAN, H. M. et al. Characteristics of accelerated disease in chronic myelogenous leukemia. Cancer, v.61, n.7, p.1441-6, Apr 1, 1988.

KANTARJIAN, H. M. et al. Chronic myelogenous leukemia in blast crisis. Analysis of 242 patients. Am. J. Med, v.83, n.3, p.445-54, Sep, 1987. 
KANTARJIAN, H. M. et al. Complete cytogenetic and molecular responses to interferonalpha-based therapy for chronic myelogenous leukemia are associated with excellent longterm prognosis. Cancer,, v.97, n.4, p.1033-41, Feb 15, 2003.

KANTARJIAN, H. M. et al. Chronic myelogenous leukemia: a multivariate analysis of the associations of patient characteristics and therapy with survival. Blood,, v.66, n.6, p.1326-35, Dec, 1985.

KANTARJIAN, H. M. et al. Imatinib mesylate for Philadelphia chromosome-positive, chronic-phase myeloid leukemia after failure of interferon-alpha: follow-up results. Clin. Cancer Res, v.8, n.7, p.2177-87, Jul, 2002b.

KHALDOYANIDI, S. K. et al. MDA-MB-435 human breast carcinoma cell homo- and heterotypic adhesion under flow conditions is mediated in part by Thomsen-Friedenreich antigen-galectin-3 interactions. J. Biol. Chem.,, v.278, n.6, p.4127-34, Feb 7, 2003.

KHARAS, M. G.; FRUMAN, D. A. ABL oncogenes and phosphoinositide 3-kinase: mechanism of activation and downstream effectors. Cancer Res, v.65, n.6, p.2047-53, Mar $15,2005$.

KHARAS, M. G. et al. Ablation of PI3K blocks BCR-ABL leukemogenesis in mice, and a dual PI3K/mTOR inhibitor prevents expansion of human BCR-ABL+ leukemia cells. J. Clin. Invest,, v.118, n.9, p.3038-50, Sep, 2008.

KIANI, A. et al. Normal intrinsic Th1/Th2 balance in patients with chronic phase chronic myeloid leukemia not treated with interferon-alpha or imatinib. Haematologica, v.88, n.7, p.754-61, Jul, 2003.

KISS, J. et al. A novel anti-inflammatory function of human galectin-1: inhibition of hematopoietic progenitor cell mobilization. Exp. Hematol,, v.35, n.2, p.305-13, Feb, 2007.

KLEJMAN, A. et al. Phosphatidylinositol-3 kinase inhibitors enhance the anti-leukemia effect of STI571. Oncogene,, v.21, n.38, p.5868-76, Aug 29, 2002.

KLUCHER, K. M. et al. Secondary mutation maintains the transformed state in BaF3 cells with inducible BCR/ABL expression. Blood,, v.91, n.10, p.3927-34, May 15, 1998.

KOLOMIETZ, E. et al. Primary chromosomal rearrangements of leukemia are frequently accompanied by extensive submicroscopic deletions and may lead to altered prognosis. Blood,, v.97, n.11, p.3581-8, Jun 1, 2001.

KOOPMAN, L. A. et al. Human decidual natural killer cells are a unique NK cell subset with immunomodulatory potential. J. Exp. Med,, v.198, n.8, p.1201-12, Oct 20, 2003.

KOPITZ, J. et al. Negative regulation of neuroblastoma cell growth by carbohydratedependent surface binding of galectin-1 and functional divergence from galectin-3. J. Biol. Chem.,, v.276, n.38, p.35917-23, Sep 21, 2001.

KURZROCK, R. et al. Expression of c-abl in Philadelphia-positive acute myelogenous leukemia. Blood, v.70, n.5, p.1584-8, Nov, 1987.

LAGGER, G. et al. The tumor suppressor p53 and histone deacetylase 1 are antagonistic regulators of the cyclin-dependent kinase inhibitor p21/WAF1/CIP1 gene. Mol. Cell. Biol, v.23, n.8, p.2669-79, Apr, 2003.

LANEUVILLE, P. Abl tyrosine protein kinase. Semin. Immunol, v.7, n.4, p.255-66, Aug, 1995. 
LANEUVILLE, $\mathrm{P}$. et al. bcr/abl expression in 32D cl3(G) cells inhibits apoptosis induced by protein tyrosine kinase inhibitors. Cancer Res,, v.54, n.5, p.1360-6, Mar 1, 1994.

LE MARER, N.; HUGHES, R. C. Effects of the carbohydrate-binding protein galectin-3 on the invasiveness of human breast carcinoma cells. J. Cell. Physiol,, v.168, n.1, p.51-8, Jul, 1996.

LEE, S. H. et al. In vivo rejection of tumor cells dependent on CD8 cells that kill independently of perforin and FasL. Cancer Gene Ther,, v.11, n.3, p.237-48, Mar, 2004.

LEWIS, J. M. et al. Integrin regulation of c-Abl tyrosine kinase activity and cytoplasmicnuclear transport. Proc. Natl. Acad. Sci. U S A,, v.93, n.26, p.15174-9, Dec 24, 1996.

LIAO, D. I. et al. Structure of S-lectin, a developmentally regulated vertebrate betagalactoside-binding protein. Proc. Natl. Acad. Sci. U S A,, v.91, n.4, p.1428-32, Feb 15, 1994.

LIDONNICI, M. R. et al. Requirement of c-Myb for p210(BCR/ABL)-dependent transformation of hematopoietic progenitors and leukemogenesis. Blood,, v.111, n.9, p.47719, May 1, 2008.

LIST, A. F. Vascular endothelial growth factor signaling pathway as an emerging target in hematologic malignancies. Oncologist,, v.6 Suppl 5, p.24-31, 2001.

LIU, F. T. et al. Intracellular functions of galectins. Biochim. Biophys. Acta, v.1572, n.2-3, p.263-73, Sep 19, 2002.

LIU, F. T.; RABINOVICH, G. A. Galectins as modulators of tumour progression. Nat. Rev. Cancer,, v.5, n.1, p.29-41, Jan, 2005.

LIU, J. et al. Sequences within the first exon of BCR inhibit the activated tyrosine kinases of c-Abl and the Bcr-Abl oncoprotein. Cancer Res,, v.56, n.22, p.5120-4, Nov 15, 1996.

LOTAN, R. et al. Modulation of galactoside-binding lectins in tumor cells by differentiationinducing agents. Cancer Lett,, v.48, n.2, p.115-22, Nov 30, 1989.

LOWE, S. W. et al. Intrinsic tumour suppression. Nature, v.432, n.7015, p.307-15, Nov 18, 2004.

LOWE, S. W.; SHERR, C. J. Tumor suppression by Ink4a-Arf: progress and puzzles. Curr. Opin. Genet. Dev,, v.13, n.1, p.77-83, Feb, 2003.

LU, Y. et al. Differential regulation of constitutive and retinoic acid-induced galectin-1 gene transcription in murine embryonal carcinoma and myoblastic cells. Biochim. Biophys. Acta, v.1491, n.1-3, p.13-9, Apr 25, 2000.

LUNDBERG, L. G. et al. Bone marrow in polycythemia vera, chronic myelocytic leukemia, and myelofibrosis has an increased vascularity. Am. J. Pathol,, v.157, n.1, p.15-9, Jul, 2000.

LUTOMSKI, D. et al. Externalization and binding of galectin-1 on cell surface of K562 cells upon erythroid differentiation. Glycobiology,, v.7, n.8, p.1193-9, Dec, 1997.

MARU, Y.; WITTE, O. N. The BCR gene encodes a novel serine/threonine kinase activity within a single exon. Cell,, v.67, n.3, p.459-68, Nov 1, 1991.

MATARRESE, P. et al. Galectin-3 overexpression protects from apoptosis by improving cell adhesion properties. Int. J. Cancer,, v.85, n.4, p.545-54, Feb 15, 2000. 
MATARRESE, P. et al. Galectin-1 sensitizes resting human T lymphocytes to Fas (CD95)mediated cell death via mitochondrial hyperpolarization, budding, and fission. J. Biol. Chem.,, v.280, n.8, p.6969-85, Feb 25, 2005.

MATSUGUCHI, T. et al. Tyrosine phosphorylation of p95Vav in myeloid cells is regulated by GM-CSF, IL-3 and steel factor and is constitutively increased by p210BCR/ABL. Embo J, v.14, n.2, p.257-65, Jan 16, 1995.

MAYERHOFER, $M$. et al. Identification of heme oxygenase-1 as a novel BCR/ABLdependent survival factor in chronic myeloid leukemia. Cancer Res,, v.64, n.9, p.3148-54, May 1, 2004.

MCCONNELL, B. B. et al. Inhibitors of cyclin-dependent kinases induce features of replicative senescence in early passage human diploid fibroblasts. Curr. Biol,, v.8, n.6, p.3514, Mar 12, 1998.

MCGAHON, A. et al. BCR-ABL maintains resistance of chronic myelogenous leukemia cells to apoptotic cell death. Blood,, v.83, n.5, p.1179-87, Mar 1, 1994.

MCWHIRTER, J. R. et al. A coiled-coil oligomerization domain of Bcr is essential for the transforming function of Bcr-Abl oncoproteins. Mol. Cell. Biol,, v.13, n.12, p.7587-95, Dec, 1993 b.

MCWHIRTER, J. R.; WANG, J. Y. An actin-binding function contributes to transformation by the Bcr-Abl oncoprotein of Philadelphia chromosome-positive human leukemias. Embo J, v.12, n.4, p.1533-46, Apr, 1993a.

MEHUL, B.; HUGHES, R. C. Plasma membrane targetting, vesicular budding and release of galectin 3 from the cytoplasm of mammalian cells during secretion. J. Cell Sci,, v.110 ( Pt 10), p.1169-78, May, 1997.

MELO, J. V. The diversity of BCR-ABL fusion proteins and their relationship to leukemia phenotype. Blood, v.88, n.7, p.2375-84, Oct 1, 1996 .

MELO, J. V. The molecular biology of chronic myeloid leukaemia. Leukemia, v.10, n.5, p.751-6, May, 1996b.

MELO, J. V.; CHUAH, C. Resistance to imatinib mesylate in chronic myeloid leukaemia. Cancer Lett,, v.249, n.2, p.121-32, May 8, 2007.

MELO, J. V.; CHUAH, C. Novel Agents in CML Therapy: Tyrosine Kinase Inhibitors and Beyond. Hematology Am. Soc. Hematol. Educ. Program,, v.2008, p.427-35, 2008.

MELO, J. V. et al. The ABL-BCR fusion gene is expressed in chronic myeloid leukemia. Blood,, v.81, n.1, p.158-65, Jan 1, 1993.

MELO, J. V. et al. Chronic myeloid leukemia. Hematology (Am Soc Hematol Educ Program),, p.132-52, 2003.

MENSSEN, A.; HERMEKING, H. Characterization of the c-MYC-regulated transcriptome by SAGE: identification and analysis of c-MYC target genes. Proc. Natl. Acad. Sci. U S A, v.99, n.9, p.6274-9, Apr 30, 2002.

MOISA, A. et al. Growth/adhesion-regulatory tissue lectin galectin-3: stromal presence but not cytoplasmic/nuclear expression in tumor cells as a negative prognostic factor in breast cancer. Anticancer Res,, v.27, n.4B, p.2131-9, Jul-Aug, 2007. 
MOTRAN, C. C. et al. Galectin-1 functions as a Th2 cytokine that selectively induces Th1 apoptosis and promotes Th2 function. Eur. J. Immunol, v.38, n.11, p.3015-27, Nov, 2008.

NAGAR, B. et al. Structural basis for the autoinhibition of c-Abl tyrosine kinase. Cell,, v.112, n.6, p.859-71, Mar 21, 2003.

NAKAHARA, S. et al. On the role of galectin-3 in cancer apoptosis. Apoptosis, v.10, n.2, p.267-75, Mar, 2005.

NAKAHARA, S.; RAZ, A. On the role of galectins in signal transduction. Methods Enzymol,, v.417, p.273-89, 2006.

NANGIA-MAKKER, P. et al. Regulation of tumor progression by extracellular galectin-3. Cancer Microenviron,, v.1, n.1, p.43-51, Dec, 2008.

NANGIA-MAKKER, P. et al. Galectin-3 induces endothelial cell morphogenesis and angiogenesis. Am. J. Pathol,, v.156, n.3, p.899-909, Mar, 2000.

NANGIA-MAKKER, P. et al. Regulation of the expression of galactoside-binding lectin during human monocytic differentiation. Cancer Res,, v.53, n.20, p.5033-7, Oct 15, 1993.

NATIONAL RESEARCH COUNCIL (U.S.). COMMITTEE TO ASSESS HEALTH RISKS FROM EXPOSURE TO LOW LEVEL OF IONIZING RADIATION. Health risks from exposure to low levels of ionizing radiation : BEIR VII Phase 2. Washington, D.C.: National Academies Press, Date., xvi, 406 p. p.2006

NESHAT, M. S. et al. The survival function of the Bcr-Abl oncogene is mediated by Baddependent and -independent pathways: roles for phosphatidylinositol 3-kinase and Raf. Mol. Cell. Biol,, v.20, n.4, p.1179-86, Feb, 2000.

NGUYEN, J. T. et al. CD45 modulates galectin-1-induced $\mathrm{T}$ cell death: regulation by expression of core 2 O-glycans. J. Immunol,, v.167, n.10, p.5697-707, Nov 15, 2001.

NISHII, K. et al. ts BCR-ABL kinase activation confers increased resistance to genotoxic damage via cell cycle block. Oncogene,, v.13, n.10, p.2225-34, Nov 21, 1996.

NORLING, L. et al. Endogenous Galectins and the control of host inflammatory response. J Endocrinol,, Jan 20, 2009.

NOVELLI, F. et al. Negative cell cycle control of human $T$ cells by beta-galactoside binding protein (beta GBP): induction of programmed cell death in leukaemic cells. J. Cell. Physiol,, v.178, n.1, p.102-8, Jan, 1999.

NOWELL, P. C.; HUNGERFORD, D. A. Chromosome studies on normal and leukemic human leukocytes. J.Natl. Cancer Inst,, v.25, p.85-109, Jul, 1960.

O'BRIEN, S. G. et al. Imatinib compared with interferon and low-dose cytarabine for newly diagnosed chronic-phase chronic myeloid leukemia. N. Engl. J. Med,, v.348, n.11, p.9941004, Mar 13, 2003.

O'DRISCOLL, L. et al. Galectin-3 expression alters adhesion, motility and invasion in a lung cell line (DLKP), in vitro. Anticancer Res,, v.22, n.6A, p.3117-25, Nov-Dec, 2002.

OCHIENG, J. et al. Extracellular functions of galectin-3. Glycoconj. J, v.19, n.7-9, p.527-35, 2004.

OCHSENBEIN, A. F. Principles of tumor immunosurveillance and implications for immunotherapy. Cancer Gene Ther,, v.9, n.12, p.1043-55, Dec, 2002. 
OGRYZKO, V. V. et al. Human fibroblast commitment to a senescence-like state in response to histone deacetylase inhibitors is cell cycle dependent. Mol. Cell Biol,, v.16, n.9, p.5210-8, Sep, 1996.

OHNISHI, K. et al. A randomized trial comparing interferon-alpha with busulfan for newly diagnosed chronic myelogenous leukemia in chronic phase. Blood, v.86, n.3, p.906-16, Aug $1,1995$.

OKUDA, K. et al. The C-terminus of c-ABL is required for proliferation and viability signaling in a c-ABL/erythropoietin receptor fusion protein. Blood,, v.92, n.10, p.3848-56, Nov 15, 1998.

PACE, K. E. et al. CD7 delivers a pro-apoptotic signal during galectin-1-induced T cell death. J. Immunol,, v.165, n.5, p.2331-4, Sep 1, 2000.

PACE, K. E. et al. Restricted receptor segregation into membrane microdomains occurs on human $\mathrm{T}$ cells during apoptosis induced by galectin-1. J. Immunol, v.163, n.7, p.3801-11, Oct 1, 1999.

PANE, F. et al. Neutrophilic-chronic myeloid leukemia: a distinct disease with a specific molecular marker (BCR/ABL with C3/A2 junction). Blood,, v.88, n.7, p.2410-4, Oct 1, 1996.

PAPAMICHAIL, M. et al. Natural killer lymphocytes: biology, development, and function. Cancer Immunol Immunother,, v.53, n.3, p.176-86, Mar, 2004.

PASTERNAK, G. et al. Chronic myelogenous leukemia: molecular and cellular aspects. J Cancer Res Clin Oncol,, v.124, n.12, p.643-60, 1998.

PAZ, A. et al. Galectin-1 binds oncogenic H-Ras to mediate Ras membrane anchorage and cell transformation. Oncogene,, v.20, n.51, p.7486-93, Nov 8, 2001.

PELLETIER, S. D. et al. Lack of the adhesion molecules P-selectin and intercellular adhesion molecule-1 accelerate the development of BCR/ABL-induced chronic myeloid leukemia-like myeloproliferative disease in mice. Blood,, v.104, n.7, p.2163-71, Oct 1, 2004.

PENDERGAST, A. M. et al. BCR sequences essential for transformation by the BCR-ABL oncogene bind to the $\mathrm{ABL} \mathrm{SH} 2$ regulatory domain in a non-phosphotyrosine-dependent manner. Cell,, v.66, n.1, p.161-71, Jul 12, 1991.

PENDERGAST, A. M. et al. BCR-ABL-induced oncogenesis is mediated by direct interaction with the SH2 domain of the GRB-2 adaptor protein. Cell, v.75, n.1, p.175-85, Oct 8, 1993.

PERAZZONA, B. et al. Kinase domain mutants of Bcr enhance Bcr-Abl oncogenic effects. Oncogene,, v.27, n.15, p.2208-14, Apr 3, 2008.

PERILLO, N. L. et al. Apoptosis of T cells mediated by galectin-1. Nature,, v.378, n.6558, p.736-9, Dec 14, 1995.

PERILLO, N. L. et al. Galectin-1, an endogenous lectin produced by thymic epithelial cells, induces apoptosis of human thymocytes. J. Exp. Med,, v.185, n.10, p.1851-8, May 19, 1997.

PERROTTI, D. et al. TLS/FUS, a pro-oncogene involved in multiple chromosomal translocations, is a novel regulator of BCR/ABL-mediated leukemogenesis. Embo J, v.17, n.15, p.4442-55, Aug 3, 1998. 
PERROTTI, D.; CALABRETTA, B. Post-transcriptional mechanisms in BCR/ABL leukemogenesis: role of shuttling RNA-binding proteins. Oncogene,, v.21, n.56, p.8577-83, Dec 9, 2002b.

PERROTTI, D. et al. BCR-ABL suppresses C/EBPalpha expression through inhibitory action of hnRNP E2. Nat. Genet,, v.30, n.1, p.48-58, Jan, 2002a.

PINILLA-IBARZ, J. et al. CML vaccines as a paradigm of the specific immunotherapy of cancer. Blood Rev,, v.14, n.2, p.111-20, Jun, 2000.

PLUK, H. et al. Autoinhibition of c-Abl. Cell,, v.108, n.2, p.247-59, Jan 25, 2002.

PORAKISHVILI, N. et al. Cytotoxic CD4+ $\mathrm{T}$ cells in patients with $\mathrm{B}$ cell chronic lymphocytic leukemia kill via a perforin-mediated pathway. Haematologica, v.89, n.4, p.43543, Apr, 2004.

PRENDERGAST, G. C.; JAFFEE, E. M. Cancer immunologists and cancer biologists: why we didn't talk then but need to now. Cancer Res,, v.67, n.8, p.3500-4, Apr 15, 2007.

PUIL, L. et al. Bcr-Abl oncoproteins bind directly to activators of the Ras signalling pathway. Embo J,, v.13, n.4, p.764-73, Feb 15, 1994.

QUACKENBUSH, R. C. et al. Analysis of the biologic properties of p230 Bcr-Abl reveals unique and overlapping properties with the oncogenic p185 and p210 Bcr-Abl tyrosine kinases. Blood,, v.95, n.9, p.2913-21, May 1, 2000.

QUINTAS-CARDAMA, A. et al. Imatinib mesylate therapy may overcome the poor prognostic significance of deletions of derivative chromosome 9 in patients with chronic myelogenous leukemia. Blood,, v.105, n.6, p.2281-6, Mar 15, 2005.

RABINOVICH, G. A. Galectins: an evolutionarily conserved family of animal lectins with multifunctional properties; a trip from the gene to clinical therapy. Cell Death Differ,, v.6, n.8, p.711-21, Aug, 1999a.

RABINOVICH, G. A. Galectin-1 as a potential cancer target. Br. J. Cancer,, v.92, n.7, p.1188-92, Apr 11, 2005.

RABINOVICH, G. A. et al. Molecular mechanisms implicated in galectin-1-induced apoptosis: activation of the AP-1 transcription factor and downregulation of Bcl-2. Cell Death Differ,, v.7, n.8, p.747-53, Aug, 2000.

RABINOVICH, G. A. et al. Specific inhibition of T-cell adhesion to extracellular matrix and proinflammatory cytokine secretion by human recombinant galectin-1. Immunology, v.97, n.1, p.100-6, May, 1999c.

RABINOVICH, G. A. et al. Galectins and their ligands: amplifiers, silencers or tuners of the inflammatory response? Trends Immunol,, v.23, n.6, p.313-20, Jun, 2002.

RABINOVICH, G. A. et al. Recombinant galectin-1 and its genetic delivery suppress collagen-induced arthritis via T cell apoptosis. J. Exp. Med,, v.190, n.3, p.385-98, Aug 2, 1999b.

RABINOVICH, G. A. et al. Immunosuppressive strategies that are mediated by tumor cells. Annu. Rev. Immunol,, v.25, p.267-96, 2007b.

RABINOVICH, G. A. et al. Specific inhibition of lymphocyte proliferation and induction of apoptosis by CLL-I, a beta-galactoside-binding lectin. J. Biochem. (Tokyo), v.122, n.2, p.365-73, Aug, 1997. 
RABINOVICH, G. A. et al. Functions of cell surface galectin-glycoprotein lattices. Curr. Opin. Struct. Biol.,, v.17, n.5, p.513-20, Oct, 2007a.

RASCHKE, W. C. et al. Oncogenic transformation of murine lymphoid cells by in vitro infection with Abelson leukemia virus. J. Natl. Cancer Inst, v.54, n.5, p.1249-53, May, 1975.

RAZ, A. et al. Transformation-related changes in the expression of endogenous cell lectins. Int. J. Cancer, v.39, n.3, p.353-60, Mar 15, 1987.

REBBAA, A. et al. The role of histone acetylation versus DNA damage in drug-induced senescence and apoptosis. Cell Death Differ,, v.13, n.11, p.1960-7, Nov, 2006.

REBOLLO, A.; MARTINEZ, A. C. Ras proteins: recent advances and new functions. Blood, v.94, n.9, p.2971-80, Nov 1, 1999.

REDAELLI, S. et al. Activity of Bosutinib, Dasatinib, and Nilotinib Against 18 ImatinibResistant BCR/ABL Mutants. J. Clin. Oncol,, Dec 15, 2008.

REUTHER, G. W. et al. Association of the protein kinases c-Bcr and Bcr-Abl with proteins of the 14-3-3 family. Science,, v.266, n.5182, p.129-33, Oct 7, 1994.

ROBLES, S. J.; ADAMI, G. R. Agents that cause DNA double strand breaks lead to p16INK4a enrichment and the premature senescence of normal fibroblasts. Oncogene,, v.16, n.9, p.1113-23, Mar 5, 1998.

ROMAN-GOMEZ, J. et al. Repetitive DNA hypomethylation in the advanced phase of chronic myeloid leukemia. Leuk. Res,, v.32, n.3, p.487-90, Mar, 2008.

RORIVE, S. et al. Galectin-1 is highly expressed in human gliomas with relevance for modulation of invasion of tumor astrocytes into the brain parenchyma. Glia, v.33, n.3, p.24155, Mar 1, 2001.

ROSENBERG, N. et al. In vitro transformation of lymphoid cells by Abelson murine leukemia virus. Proc. Natl. Acad. Sci. U S A,, v.72, n.5, p.1932-6, May, 1975.

ROWLEY, J. D. Chromosomal patterns in myelocytic leukemia. N. Engl. J. Med, v.289, n.4, p.220-1, Jul 26, 1973.

RUBINSTEIN, N. et al. Targeted inhibition of galectin-1 gene expression in tumor cells results in heightened $\mathrm{T}$ cell-mediated rejection; A potential mechanism of tumor-immune privilege. Cancer Cell, v.5, n.3, p.241-51, Mar, 2004.

RUTZ, S.; SCHEFFOLD, A. Towards in vivo application of RNA interference - new toys, old problems. Arthritis Res. Ther,, v.6, n.2, p.78-85, 2004.

SABHERWAL, Y. et al. Integrin alpha2beta1 mediates the anti-angiogenic and anti-tumor activities of angiocidin, a novel tumor-associated protein. Exp. Cell Res,, v.312, n.13, p.244353, Aug 1, 2006.

SACCHETTINI, J. C. et al. Multivalent protein-carbohydrate interactions. A new paradigm for supermolecular assembly and signal transduction. Biochem.istry,, v.40, n.10, p.3009-15, Mar 13, 2001.

SAGE, J. et al. Targeted disruption of the three Rb-related genes leads to loss of G(1) control and immortalization. Genes Dev, v.14, n.23, p.3037-50, Dec 1, 2000.

SALGIA, R. et al. Increased tyrosine phosphorylation of focal adhesion proteins in myeloid cell lines expressing p210BCR/ABL. Oncogene,, v.11, n.6, p.1149-55, Sep 21, 1995. 
SALVATORE, P. et al. Galectin-1 gene expression and methylation state in human $\mathrm{T}$ leukemia cell lines. Int. J. Oncol,, v.17, n.5, p.1015-8, Nov, 2000.

SALVATORE, P. et al. Characterization and functional dissection of the galectin-1 gene promoter. FEBS Lett,, v.373, n.2, p.159-63, Oct 9, 1995.

SAMBROOK, J. et al. Molecular Cloning: A Laboratory Manual. Cold Spring Harbor, N.Y.: Cold Spring Harbor Laboratory Press, Date. 1989

SAMBROOK, J.; RUSSELL, D. W. Calcium-phosphate-mediated Transfection of Eukaryotic Cells with Plasmid DNAs. 2006: pdb.prot3871- p. 2006.

SANCHEZ-GARCIA, I.; GRUTZ, G. Tumorigenic activity of the BCR-ABL oncogenes is mediated by BCL2. Proc. Natl. Acad. Sci. U S A,, v.92, n.12, p.5287-91, Jun 6, 1995.

SANJUAN, X. et al. Differential expression of galectin 3 and galectin 1 in colorectal cancer progression. Gastroenterology,, v.113, n.6, p.1906-15, Dec, 1997.

SANTUCCI, L. et al. Galectin-1 exerts immunomodulatory and protective effects on concanavalin A-induced hepatitis in mice. Hepatology, v.31, n.2, p.399-406, Feb, 2000.

SATO, S.; HUGHES, R. C. Regulation of secretion and surface expression of Mac-2, a galactoside-binding protein of macrophages. J. Biol. Chem.,, v.269, n.6, p.4424-30, Feb 11, 1994.

SATTLER, M.; SALGIA, R. Activation of hematopoietic growth factor signal transduction pathways by the human oncogene BCR/ABL. Cytokine Growth Factor Rev,, v.8, n.1, p.6379, Mar, 1997.

SATTLER, M. et al. SHIP1, an SH2 domain containing polyinositol-5-phosphatase, regulates migration through two critical tyrosine residues and forms a novel signaling complex with DOK1 and CRKL. J. Biol. Chem.,, v.276, n.4, p.2451-8, Jan 26, 2001.

SAVAGE, D. G. et al. Clinical features at diagnosis in 430 patients with chronic myeloid leukaemia seen at a referral centre over a 16-year period. Br. J. Haematol,, v.96, n.1, p.111-6, Jan, 1997.

SAWYERS, C. L. Chronic myeloid leukemia. N. Engl. J. Med, v.340, n.17, p.1330-40, Apr 29, 1999.

SAWYERS, C. L. et al. Dominant negative MYC blocks transformation by ABL oncogenes. Cell,, v.70, n.6, p.901-10, Sep 18, 1992.

SAWYERS, C. L. et al. Imatinib induces hematologic and cytogenetic responses in patients with chronic myelogenous leukemia in myeloid blast crisis: results of a phase II study. Blood,, v.99, n.10, p.3530-9, May 15, 2002.

SAWYERS, C. L. et al. Genetic requirement for Ras in the transformation of fibroblasts and hematopoietic cells by the Bcr-Abl oncogene. J. Exp. Med,, v.181, n.1, p.307-13, Jan 1, 1995.

SCHER, C. D.; SIEGLER, R. Direct transformation of 3T3 cells by Abelson murine leukaemia virus. Nature,, v.253, n.5494, p.729-31, Feb 27, 1975.

SCHINDLER, T. et al. Structural mechanism for STI-571 inhibition of abelson tyrosine kinase. Science,, v.289, n.5486, p.1938-42, Sep 15, 2000.

SCOTT, K.; WEINBERG, C. Galectin-1: a bifunctional regulator of cellular proliferation. Glycoconj. J,, v.19, n.7-9, p.467-77, 2004. 
SEELENMEYER, C. et al. Unconventional secretion of fibroblast growth factor 2 and galectin-1 does not require shedding of plasma membrane-derived vesicles. FEBS Lett,, v.582, n.9, p.1362-8, Apr 16, 2008.

SEELENMEYER, C. et al. Cell surface counter receptors are essential components of the unconventional export machinery of galectin-1. J. Cell Biol.,, v.171, n.2, p.373-81, Oct 24, 2005 .

SEETHARAMAN, J. et al. X-ray crystal structure of the human galectin-3 carbohydrate recognition domain at 2.1-A resolution. J. Biol. Chem.,, v.273, n.21, p.13047-52, May 22, 1998.

SERRANO, M. et al. Oncogenic ras provokes premature cell senescence associated with accumulation of p53 and p16INK4a. Cell,, v.88, n.5, p.593-602, Mar 7, 1997.

SEXL, V. et al. Stat5a/b contribute to interleukin 7-induced B-cell precursor expansion, but abl- and bcr/abl-induced transformation are independent of stat5. Blood,, v.96, n.6, p.2277-83, Sep 15, 2000.

SHAH, N. P. et al. Multiple BCR-ABL kinase domain mutations confer polyclonal resistance to the tyrosine kinase inhibitor imatinib (STI571) in chronic phase and blast crisis chronic myeloid leukemia. Cancer Cell,, v.2, n.2, p.117-25, Aug, 2002.

SHAH, N. P. et al. Overriding imatinib resistance with a novel ABL kinase inhibitor. Science,, v.305, n.5682, p.399-401, Jul 16, 2004.

SHALOM-FEUERSTEIN, R. et al. K-ras nanoclustering is subverted by overexpression of the scaffold protein galectin-3. Cancer Res,, v.68, n.16, p.6608-16, Aug 15, 2008.

SHERR, C. J. Tumor surveillance via the ARF-p53 pathway. Genes Dev,, v.12, n.19, p.298491, Oct 1, 1998.

SHERR, C. J. Principles of tumor suppression. Cell, v.116, n.2, p.235-46, Jan 23, 2004.

SHERR, C. J.; MCCORMICK, F. The RB and p53 pathways in cancer. Cancer Cell,, v.2, n.2, p.103-12, Aug, 2002.

SHI, Y. et al. Abl-interactor-1, a novel SH3 protein binding to the carboxy-terminal portion of the Abl protein, suppresses v-abl transforming activity. Genes Dev,, v.9, n.21, p.2583-97, Nov $1,1995$.

SIRARD, C. et al. Expression of bcr-abl abrogates factor-dependent growth of human hematopoietic M07E cells by an autocrine mechanism. Blood, v.83, n.6, p.1575-85, Mar 15, 1994.

SKORSKI, T. et al. Transformation of hematopoietic cells by BCR/ABL requires activation of a PI-3k/Akt-dependent pathway. Embo J,, v.16, n.20, p.6151-61, Oct 15, 1997.

SKORSKI, T. et al. Phosphatidylinositol-3 kinase activity is regulated by BCR/ABL and is required for the growth of Philadelphia chromosome-positive cells. Blood, v.86, n.2, p.72636, Jul 15, 1995.

SKRINCOSKY, D. M. et al. Galaptin-mediated adhesion of human ovarian carcinoma A121 cells and detection of cellular galaptin-binding glycoproteins. Cancer Res,, v.53, n.11, p.266775, Jun 1, 1993.

SMITH, K. M. et al. Autoinhibition of Bcr-Abl through its SH3 domain. Mol. Cell,, v.12, n.1, p.27-37, Jul, 2003. 
SMYTH, M. J. et al. Cutting edge: granzymes A and B are not essential for perforin-mediated tumor rejection. J. Immunol, v.171, n.2, p.515-8, Jul 15, 2003 b.

SOGN, J. A. Tumor immunology: the glass is half full. Immunity,, v.9, n.6, p.757-63, Dec, 1998.

SOKAL, J. E. et al. Prognostic discrimination in "good-risk" chronic granulocytic leukemia. Blood,, v.63, n.4, p.789-99, Apr, 1984.

SPECK, B. et al. Allogeneic bone-marrow transplantation for chronic myelogenous leukaemia. Lancet,, v.1, n.8378, p.665-8, Mar 24, 1984.

STILLMAN, B. N. et al. Galectin-3 and galectin-1 bind distinct cell surface glycoprotein receptors to induce T cell death. J. Immunol, v.176, n.2, p.778-89, Jan 15, 2006.

TABRIZI, S. J. et al. T cell leukemia/lymphoma 1 and galectin-1 regulate survival/cell death pathways in human naive and IgM+ memory B cells through altering balances in Bcl-2 family proteins. J. Immunol, v.182, n.3, p.1490-9, Feb 1, 2009.

TAKEDA, K. et al. Critical role for tumor necrosis factor-related apoptosis-inducing ligand in immune surveillance against tumor development. J. Exp. Med,, v.195, n.2, p.161-9, Jan 21, 2002.

TAKEDA, N. et al. The BCR-ABL oncoprotein potentially interacts with the xeroderma pigmentosum group B protein. Proc. Natl. Acad. Sci. U S A,, v.96, n.1, p.203-7, Jan 5, 1999.

TAKENAKA, Y. et al. Nuclear export of phosphorylated galectin-3 regulates its antiapoptotic activity in response to chemotherapeutic drugs. Mol. Cell Biol,, v.24, n.10, p.4395-406, May, 2004.

TAKENAKA, Y. et al. Malignant transformation of thyroid follicular cells by galectin-3. Cancer Lett,, v.195, n.1, p.111-9, May 30, 2003.

TALPAZ, M. et al. Leukocyte interferon-induced myeloid cytoreduction in chronic myelogenous leukemia. Blood,, v.62, n.3, p.689-92, Sep, 1983.

TALPAZ, M. et al. Imatinib induces durable hematologic and cytogenetic responses in patients with accelerated phase chronic myeloid leukemia: results of a phase 2 study. Blood, v.99, n.6, p.1928-37, Mar 15, 2002.

TAO, W. J. et al. BCR-ABL oncogenic transformation of NIH $3 \mathrm{~T} 3$ fibroblasts requires the IL-3 receptor. Oncogene,, v.27, n.22, p.3194-200, May 15, 2008.

TEJLER, J. et al. Synthesis of multivalent lactose derivatives by 1,3-dipolar cycloadditions: selective galectin-1 inhibition. Carbohydr. Res, v.341, n.10, p.1353-62, Jul 24, 2006.

THIJSSEN, V. L. et al. Galectin-1 is essential in tumor angiogenesis and is a target for antiangiogenesis therapy. Proc. Natl. Acad. Sci. U S A,, v.103, n.43, p.15975-80, Oct 24, 2006.

THOMAS, J. et al. Active transport of imatinib into and out of cells: implications for drug resistance. Blood, v.104, n.12, p.3739-45, Dec 1, 2004.

TINARI, N. et al. Glycoprotein 90K/MAC-2BP interacts with galectin-1 and mediates galectin-1-induced cell aggregation. Int. J. Cancer,, v.91, n.2, p.167-72, Jan 15, 2001.

TOSCANO, M. A. et al. Differential glycosylation of TH1, TH2 and TH-17 effector cells selectively regulates susceptibility to cell death. Nat. Immunol,, v.8, n.8, p.825-34, Aug, 2007. 
TOSCANO, M. A. et al. Galectin-1 suppresses autoimmune retinal disease by promoting concomitant Th2- and $\mathrm{T}$ regulatory-mediated anti-inflammatory responses. J. Immunol, v.176, n.10, p.6323-32, May 15, 2006.

TRAINA, F. et al. BCR-ABL binds to IRS-1 and IRS-1 phosphorylation is inhibited by imatinib in K562 cells. FEBS Lett,, v.535, n.1-3, p.17-22, Jan 30, 2003.

TSIFTSOGLOU, A. S. et al. Mechanisms involved in the induced differentiation of leukemia cells. Pharmacol. Ther, v.100, n.3, p.257-90, Dec, 2003.

ULKU, A. S.; DER, C. J. Ras signaling, deregulation of gene expression and oncogenesis. Cancer Treat. Res,, v.115, p.189-208, 2003.

VAN DEN BRULE, F. et al. Galectin-1 accumulation in the ovary carcinoma peritumoral stroma is induced by ovary carcinoma cells and affects both cancer cell proliferation and adhesion to laminin-1 and fibronectin. Lab. Invest,, v.83, n.3, p.377-86, Mar, 2003.

VAN DEN BRULE, F. A. et al. Galectin-1 modulates human melanoma cell adhesion to laminin. Biochem. Biophys. Res. Commun,, v.209, n.2, p.760-7, Apr 17, 1995.

VAN DER LEIJ, J. et al. Strongly enhanced IL-10 production using stable galectin-1 homodimers. Mol. Immunol,, v.44, n.4, p.506-13, Jan, 2007.

VAN ETTEN, R. A. Cycling, stressed-out and nervous: cellular functions of c-Abl. Trends Cell Biol.,, v.9, n.5, p.179-86, May, 1999.

VAN ETTEN, R. A. et al. The mouse type IV c-abl gene product is a nuclear protein, and activation of transforming ability is associated with cytoplasmic localization. Cell,, v.58, n.4, p.669-78, Aug 25, 1989.

VARDIMAN, J. W. et al. The World Health Organization (WHO) classification of the myeloid neoplasms. Blood,, v.100, n.7, p.2292-302, Oct 1, 2002.

VARTICOVSKI, L. et al. Activation of phosphatidylinositol 3-kinase in cells expressing abl oncogene variants. Mol. Cell Biol.,, v.11, n.2, p.1107-13, Feb, 1991.

VAS, V. et al. Biphasic effect of recombinant galectin-1 on the growth and death of early hematopoietic cells. Stem Cells,, v.23, n.2, p.279-87, Feb, 2005.

VAZ DE CAMPOS, M. G. et al. Clinical implications of der(9q) deletions detected through dual-fusion fluorescence in situ hybridization in patients with chronic myeloid leukemia. Cancer Genet. Cytogenet,, v.178, n.1, p.49-56, Oct 1, 2007.

VAZIRI, H.; BENCHIMOL, S. Reconstitution of telomerase activity in normal human cells leads to elongation of telomeres and extended replicative life span. Curr. Biol.,, v.8, n.5, p.279-82, Feb 26, 1998.

VERFAILLIE, C. M. Direct contact between human primitive hematopoietic progenitors and bone marrow stroma is not required for long-term in vitro hematopoiesis. Blood,, v.79, n.11, p.2821-6, Jun 1, 1992.

VERMA, D. S. et al. Human leukocyte interferon preparation blocks granulopoietic differentiation. Blood, v.54, n.6, p.1423-7, Dec, 1979.

VESPA, G. N. et al. Galectin-1 specifically modulates TCR signals to enhance TCR apoptosis but inhibit IL-2 production and proliferation. J. Immunol,, v.162, n.2, p.799-806, Jan 15, 1999. 
VIGNERI, P.; WANG, J. Y. Induction of apoptosis in chronic myelogenous leukemia cells through nuclear entrapment of BCR-ABL tyrosine kinase. Nat. Med,, v.7, n.2, p.228-34, Feb, 2001.

VONCKEN, J. W. et al. Increased neutrophil respiratory burst in bcr-null mutants. Cell,, v.80, n.5, p.719-28, Mar 10, 1995.

WANG, J. Y. Regulation of cell death by the Abl tyrosine kinase. Oncogene, v.19, n.49, p.5643-50, Nov 20, 2000.

WANG, Z. et al. Disruption of the inhibitor of apoptosis protein survivin sensitizes Bcr-ablpositive cells to STI571-induced apoptosis. Cancer Res,, v.65, n.18, p.8224-32, Sep 15, 2005.

WATARI, K. et al. Identification of a melanoma antigen, PRAME, as a BCR/ABL-inducible gene. FEBS Lett, v.466, n.2-3, p.367-71, Jan 28, 2000.

WEN, S. T.; VAN ETTEN, R. A. The PAG gene product, a stress-induced protein with antioxidant properties, is an $\mathrm{Abl} \mathrm{SH} 3$-binding protein and a physiological inhibitor of c-Abl tyrosine kinase activity. Genes Dev,, v.11, n.19, p.2456-67, Oct 1, 1997.

WERTHEIM, J. A. et al. BCR-ABL-induced adhesion defects are tyrosine kinaseindependent. Blood,, v.99, n.11, p.4122-30, Jun 1, 2002.

WHITE, D. L. et al. Most CML patients who have a suboptimal response to imatinib have low OCT-1 activity: higher doses of imatinib may overcome the negative impact of low OCT1 activity. Blood,, v.110, n.12, p.4064-72, Dec 1, 2007.

WOOD, K. W. et al. ras mediates nerve growth factor receptor modulation of three signaltransducing protein kinases: MAP kinase, Raf-1, and RSK. Cell,, v.68, n.6, p.1041-50, Mar 20, 1992.

WOODRING, P. J. et al. Regulation of F-actin-dependent processes by the Abl family of tyrosine kinases. J Cell Sci,, v.116, n.Pt 13, p.2613-26, Jul 1, 2003.

WU, J.; LANIER, L. L. Natural killer cells and cancer. Adv. Cancer Res, v.90, p.127-56, 2003.

WYLLIE, A. H. et al. Cell death: the significance of apoptosis. Int. Rev. Cytol,, v.68, p.251306, 1980.

XIE, S. et al. Jak2 is involved in c-Myc induction by Bcr-Abl. Oncogene, v.21, n.47, p.713746, Oct 17, 2002.

XU, X. C. et al. Differential expression of galectin-1 and galectin-3 in thyroid tumors. Potential diagnostic implications. Am. J. Pathol,, v.147, n.3, p.815-22, Sep, 1995.

XUE, W. et al. Senescence and tumour clearance is triggered by p53 restoration in murine liver carcinomas. Nature,, v.445, n.7128, p.656-60, Feb 8, 2007.

YAMAOKA, K. et al. Expression of galectin-1 mRNA correlates with the malignant potential of human gliomas and expression of antisense galectin-1 inhibits the growth of 9 glioma cells. J Neurosci. Res, v.59, n.6, p.722-30, Mar 15, 2000..

YANG, R. Y. et al. Expression of galectin-3 modulates T-cell growth and apoptosis. Proc. Natl. Acad. Sci. U S A, v.93, n.13, p.6737-42, Jun 25, 1996.

YANG, R. Y. et al. Galectins: structure, function and therapeutic potential. Expert. Rev. Mol. Med,, v.10, p.e17, 2008. 
YOSHIDA, K. Nuclear trafficking of pro-apoptotic kinases in response to DNA damage. Trends Mol Med,, v.14, n.7, p.305-13, Jul, 2008.

YOSHII, T. et al. Galectin-3 phosphorylation is required for its anti-apoptotic function and cell cycle arrest. J. Biol. Chem.,, v.277, n.9, p.6852-7, Mar 1, 2002.

YOSHII, T. et al. Galectin-3 maintains the transformed phenotype of thyroid papillary carcinoma cells. Int. J. Oncol,, v.18, n.4, p.787-92, Apr, 2001.

YU, F. et al. Galectin-3 translocates to the perinuclear membranes and inhibits cytochrome c release from the mitochondria. A role for synexin in galectin-3 translocation. J. Biol. Chem.,, v.277, n.18, p.15819-27, May 3, 2002.

ZERMATI, Y. et al. Effect of tyrosine kinase inhibitor STI571 on the kinase activity of wildtype and various mutated c-kit receptors found in mast cell neoplasms. Oncogene, v.22, n.5, p.660-4, Feb 6, 2003.

ZHOU, Q.; CUMMINGS, R. D. L-14 lectin recognition of laminin and its promotion of in vitro cell adhesion. Arch. Biochem. Biophys,, v.300, n.1, p.6-17, Jan, 1993.

ZHU, J. et al. Senescence of human fibroblasts induced by oncogenic Raf. Genes Dev, v.12, n.19, p.2997-3007, Oct 1, 1998. 